\title{
Atmospheric Contributors to Heavy Rainfall Events in the Arkansas-Red River Basin
}

\author{
Taylor A. McCorkle, ${ }^{1,2}$ Skylar S. Williams, ${ }^{1,3}$ Timothy A. Pfeiffer, ${ }^{1,4}$ and Jeffrey B. Basara ${ }^{1,5}$ \\ ${ }^{1}$ School of Meteorology, University of Oklahoma, Norman, OK, USA \\ ${ }^{2}$ Department of Atmospheric Sciences, University of Utah, Salt Lake City, UT 84112-0102, USA \\ ${ }^{3}$ Department of Atmospheric and Oceanic Sciences, University of Wisconsin-Madison, Madison, WI, USA \\ ${ }^{4}$ Department of Mechanical and Industrial Engineering, University of Massachusetts, Amherst, MA, USA \\ ${ }^{5}$ Oklahoma Climatological Survey, Norman, OK, USA
}

Correspondence should be addressed to Taylor A. McCorkle; taylor.mccorkle@utah.edu

Received 22 June 2015; Accepted 3 November 2015

Academic Editor: Christophe Cudennec

Copyright (C) 2016 Taylor A. McCorkle et al. This is an open access article distributed under the Creative Commons Attribution License, which permits unrestricted use, distribution, and reproduction in any medium, provided the original work is properly cited.

\begin{abstract}
This study analyzed the top 1\% 24-hour rainfall events from 1994 to 2013 at eight climatological sites that represent the east to west precipitation gradient across the Arkansas-Red River Basin in North America. A total of 131 cases were identified and subsequently classified on the synoptic-scale, mesoscale, and local-scale to compile a climatological analysis of these extreme, heavy rainfall events based on atmospheric forcings. For each location, the prominent midtropospheric pattern, mesoscale feature, and predetermined thermodynamic variables were used to classify each $1 \%$ rainfall event. Individual events were then compared with other cases throughout the basin. The most profound results were that the magnitudes of the thermodynamic variables such as convective available potential energy and precipitable water values were poor predictors of the amount of rainfall produced in these extreme events. Further, the mesoscale forcings had more of an impact during the warm season and for the westernmost locations, whereas synoptic forcings were extremely prevalent during the cold season at the easternmost locations in the basin. The implications of this research are aimed at improving the forecasting of heavy precipitation at individual weather forecasts offices within the basin through the identified patterns at various scales.
\end{abstract}

\section{Introduction}

In the United States, flash flooding is the most deadly natural hazard with an average of 89 deaths per year and $\$ 8.2$ billion in damages. In comparison, approximately 60 people die from tornadoes each year $[1,2]$. Not only is flash flooding difficult to forecast, but it is often overlooked as a life-threatening event [3]. To the average person, heavy or extreme rainfall events are usually synonymous with flash flooding. Unfortunately, no set method for quantitatively classifying a rain event as a flash flood exists and it is subjective to the geographic location and type of event.

Flash flooding causes strong flows in rivers, creeks, and other waterways [4] usually created by extreme rainfall with high rainfall rates associated with convection [5-7]. Doswell et al. [3] state that an ingredient for flash flooding is heavy precipitation (where the rainfall rate is the highest for the longest period of time). However, many other factors contribute to flash flooding such as the characteristics of the land on which the rain falls and surface runoff occurs (area, length, slope, shape, type of soil, and vegetation) and antecedent conditions of the land [5-7]. Intense rainfall occurring on saturated soils leads to higher runoff production and the risk of flash flooding increases [8]. The urbanization of land can also enhance runoff by covering natural soils with impermeable surfaces. Similarly, land impacted by wildfires will have enhanced runoff since the vegetation that has been removed no longer intercepts rainfall $[5,6,8,9]$. The topography of the land on which rain falls determines the streamflow of the runoff and it has been found that the slope of the region enhances rapid concentration of streamflow. As a basin's steepness decreases, it is observed that the basin 
30-year normal precipitation: annual Period: 1981-2010

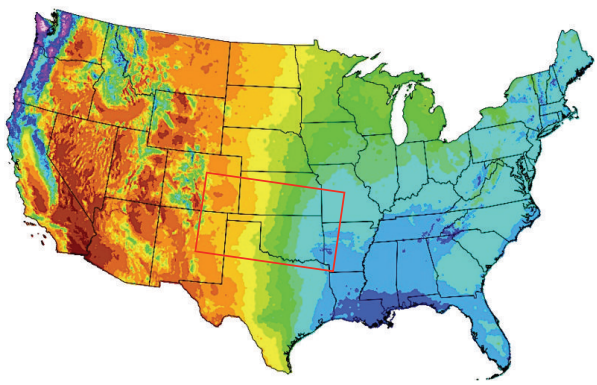

Annual precipitation (in.)

$\begin{array}{ll}\square \text { 0 } & \square 36-40 \\ \square-8 & \square 40-50 \\ 4-8 & \square 0-60 \\ 8 \text { 8 } 12 & \square 0-70 \\ 12-16 & \square 70-80 \\ \square 16-20 & \square 80-100 \\ \square 20-24 & \square 100-120 \\ \square 24-28 & \square 120-140 \\ \square 28-32 & \square 140-160 \\ \square 32-36 & \square>160\end{array}$

Copyright (c) 2013, PRISM Climate Group, Oregon State University 30-year normal mean temperature: annual Period: 1981-2010

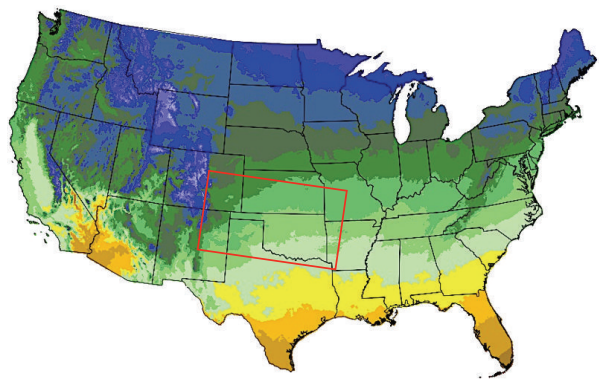

Temperature $\left({ }^{\circ} \mathrm{F}\right)$

\begin{tabular}{|c|c|}
\hline$\square<0$ & $\square 46-50$ \\
\hline$\square 0-3$ & $\square 50-54$ \\
\hline$\square 3-7$ & $\square$ 54-57 \\
\hline $7-10$ & $\square 57-61$ \\
\hline $10-14$ & $\square$ 61-64 \\
\hline $14-18$ & $\square$ 64-68 \\
\hline $18-21$ & $\square 68-72$ \\
\hline$\square 21-25$ & $\square 72-75$ \\
\hline$\square 25-28$ & $\square 75-79$ \\
\hline $28-32$ & $\square 79-82$ \\
\hline $32-36$ & $\square$ 82-86 \\
\hline$\square$ 36-39 & $\square 86-90$ \\
\hline $39-43$ & $>90$ \\
\hline$\square 43-46$ & \\
\hline
\end{tabular}

Copyright (C) 2013, PRISM Climate Group, Oregon State University

FIGURE 1: It shows the precipitation and temperature gradients across the United States. In the Arkansas-Red River Basin, the precipitation gradient is orthogonal to the temperature gradient. Approximate area encompassed by basin is outlined in red. Images via PRISM Climate Group [10].

area increases [5]. Flash flooding is not always caused by heavy rainfall but knowledge of the spatial and temporal distribution of heavy rainfall can lead to an improvement in the forecasting of flash floods [11]. Funk [12] discusses the importance of pattern recognition skills in forecasting heavy precipitation and the significance of being able to recall past heavy rainfall events along with the synoptic and mesoscale environments. With flash flood frequency expected to increase in the future due to climate change $[7,13,14]$, it is important to examine the causes of flash floods, especially extreme rainfall events.

Multiple studies have examined flash flood forecasting as well as the characteristics of extreme rainfall events. Maddox et al. [15] investigated flash flooding events and outlined characteristics of different types of events that cause heavy rainfall. Similarly, Schumacher and Johnson [16] and S. T. Ashley and W. S. Ashley [17] classified meteorological conditions that produced heavy rainfall as mesoscale convective systems (MCS), a synoptic system, or a tropical system based on radar reflectivity. Further, Schumacher and Johnson [16] classified the type of MCS as either training line/adjoining stratiform or backbuilding/quasi-stationary [18]. Doswell et al. [3] examined the ingredients of flash flooding and the storm type in each event. The authors focused on specific case studies beginning with the day preceding the event and examined the $500 \mathrm{mb}$ maps, isentropic analyses, and atmospheric profiles to determine a "nonevent" day versus an "event" day [3]. Taking these past studies into account, a methodology was formed to classify an extreme rainfall event from the synoptic-scale to the local-scale.

It is important to determine the atmospheric characteristics that work together to produce an environment conducive to the production of a heavy rainfall event. Using ensemble forecasts, Schumacher [19] analyzed the factors leading to the development of a warm season heavy rain event. The authors found that small changes in atmospheric factors, such as wind shear, played a significant role in producing large quantities of rain and how small variations in parameters can produce much different results than were expected.

Due to the spatial and temporal variability of heavy precipitation in the Great Plains region of the United States, the purpose of this study was to determine the synoptic and mesoscale forcings that drive heavy rainfall events in the region. Further, this study focused on the Arkansas-Red River Basin due to (1) the strong annual precipitation gradient that rapidly decreases from east to west and is orthogonal to the temperature gradient over a relatively small area (Figures 1 and 2) and (2) the abundance of available in situ and 


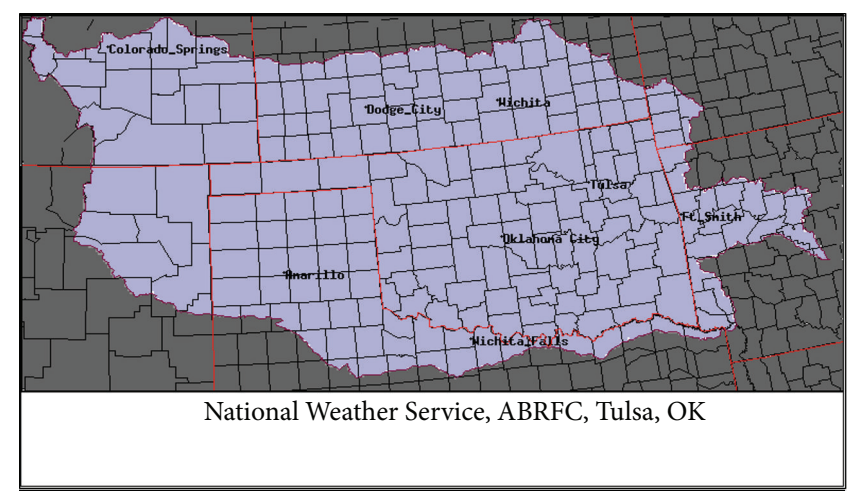

Figure 2: The Arkansas-Red River Basin. Image from the National Weather Service River Forecast Center: Arkansas-Red Basin [20].

radar observations across the domain. The results filtered by location, classification of atmospheric forcing, and annual variation are critical for improving forecasting of heavy rainfall and overall flood preparedness throughout the basin. Not only will these results help improve daily forecasting accuracy, but also they will improve climatological forecasts, which have countless socioeconomic implications [11].

Further, these heavy rainfall events play an important role in the southern Great Plains water budget as well as in influencing agriculture and ecosystem structure [21, 22]. It was documented that along regional precipitation gradients similar to that found in the Arkansas-Red River Basin, trace gases fluxes [23] and decomposition of organic matter [24] vary in response to the gradient. Both of these processes impact the plant life and ecosystems that can be supported in the area. The thriving agriculture found along this precipitation gradient supports a positive feedback to precipitating weather systems propagating over the southern Great Plains. Enhanced areas of evapotranspiration provide moisture in the low levels of the atmosphere which acts to strengthen convective storms, especially in the western locations of the basin such as Amarillo, TX [25]. In contrast, a lack of precipitation reduces soil moisture values, thus reducing possible evapotranspiration by agriculture. This positive feedback mechanism works similarly to years with enhanced precipitation but instead will produce regional drought [2628]. An example of this positive feedback drought mechanism was seen in the Arkansas-Red River Basin in the summer of 1998 due partly to anomalously low soil moisture values which enhanced the dryness in the area [29].

\section{Data and Methodology}

Eight locations were chosen to represent the north, south, east, and west boundaries and the central portion of the Arkansas-Red River Basin: Ft. Smith, AR; Tulsa, OK; Wichita, KS; Oklahoma City, OK; Wichita Falls, TX; Dodge City, KS; Amarillo, TX; and Colorado Springs, CO. The study length spanning 1994 to 2013 was chosen to include adequate WSR$88 \mathrm{D}$ radar data coverage across the basin. Using the 24-hour precipitation data from the Global Historical Climatology
Network- (GHCN-) Daily dataset, the top $1 \%$ of rainfall events were determined using days that had measureable precipitation [30]. Annual rainfall accumulations for the period of the study were created to visualize the occurrence of rainfall within the basin at each location and to find any noticeable trends in time of high rainfall accumulations between the different years (Figure 3). Using the top $1 \%$ of rainfall events allowed for the study encompassing truly "extreme" rainfall events. It is important to note that Dodge City had a single $1 \%$ precipitation event that occurred from November to March that was excluded because it was a freezing rain event and this study focuses solely on entirely liquid precipitation.

To further investigate each case, the forecast funnel approach was utilized to examine each event at the synopticscale and then the mesoscale and finally on the local-scale, similar to a method used by S. T. Ashley and W. S. Ashley [17]. The North American Regional Reanalysis (NARR) was used due to its reputation and use for identifying precipitation patterns in the United States [31]. Using the NARR, a 5-day window leading up the $1 \%$ rainfall date was viewed in order to determine the synoptic pattern at $500 \mathrm{mb}$ for each case. The classifications on the synoptic-scale, as well as the mesoscale, were inspired by a combination of the classifications used in studies from Doswell et al. [3], Maddox et al. [15], and Schumacher and Johnson [16]. Synoptic classifications determined for the cases included the following: positively tilted trough, neutrally tilted trough, negatively tilted trough, short wave, ridge, and tropical influence. Mesoscale classifications were determined via in situ and radar observations. The mesoscale classifications included the following: mesoscale convective system (MCS), stratiform rain, convection forming along a frontal or outflow boundary (does not include MCS type of events), and disorganized convection. It is important to note that an event may fall into multiple mesoscale classifications but, for consistency, the classification most prominent for the entire event was chosen.

To examine the local-scale, archived soundings were gathered for the day of each rainfall event. The sounding location (Table 1) was determined by proximity and by comparing the sounding location and the station location to a precipitable water climatology map [32]. From these soundings, 


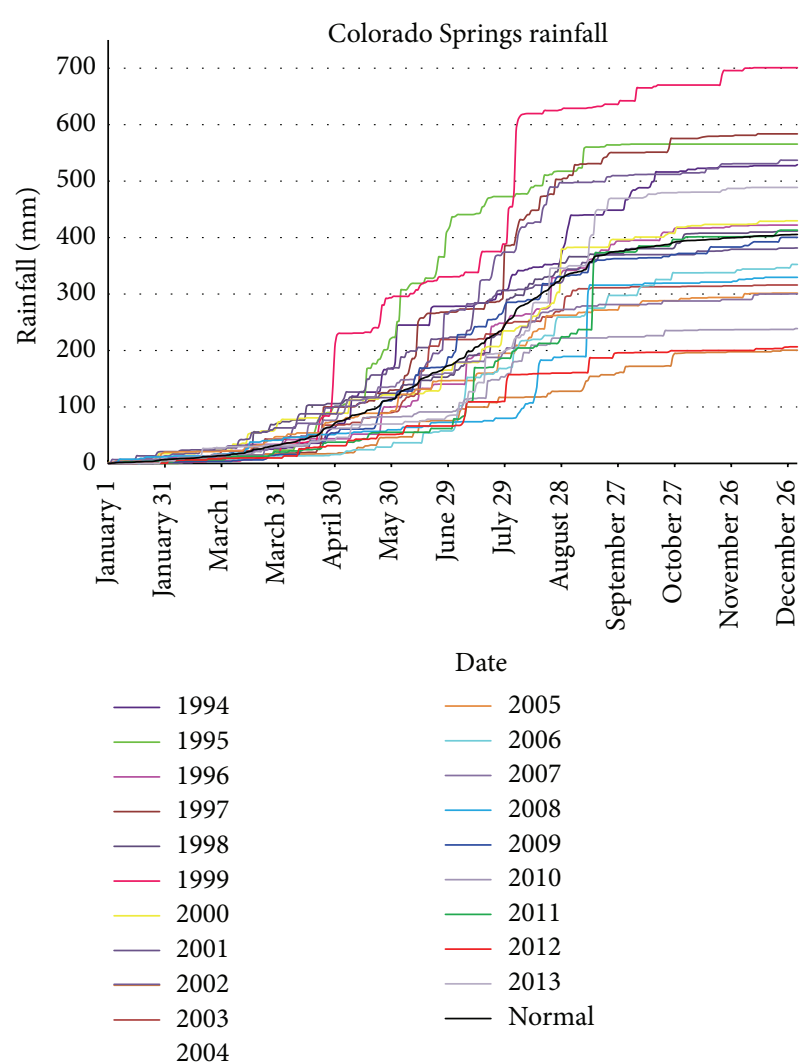

(a)

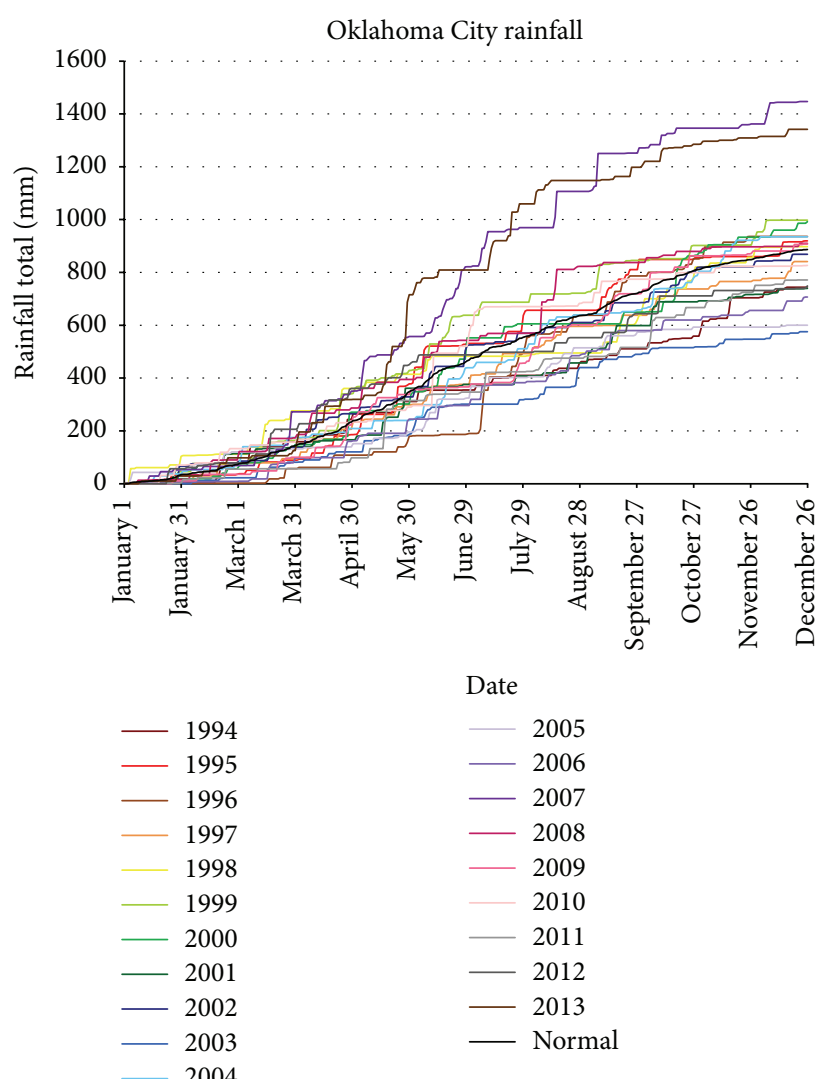

(b)

FIgURE 3: Annual rainfall accumulations for 1994-2013 for (a) Colorado Springs, CO, and (b) Oklahoma City, OK.

TABLE 1: Locations chosen.

\begin{tabular}{lcc}
\hline Location & $\begin{array}{c}\text { Number of } \\
\text { cases }\end{array}$ & $\begin{array}{c}\text { Location of proximity } \\
\text { soundings }\end{array}$ \\
\hline Ft. Smith, AR & 20 & $\begin{array}{c}\text { Little Rock, AR } \\
\text { Tulsa, OK }\end{array}$ \\
Wichita, KS & 18 & Springfield, MO, \& Norman, \\
Oklahoma City, OK & 15 & Dodge City, KS \\
Wichita Falls, TX & 14 & Norman, OK \\
Dodge City, KS & 15 & Dallas-Fort Worth, TX \\
Amarillo, TX & 14 & Dodge City, KS \\
Colorado Springs, CO & 17 & Amarillo, TX \\
\hline
\end{tabular}

variables were collected including precipitable water (PWater), convective available potential energy (CAPE), lifted condensation level (LCL), freezing level, mixed level mixing ratio (MLMR), $-10^{\circ} \mathrm{C}$ level, warm cloud depth (WCD), and $K$-Index. The vertical wind profiles, along with archived maps from the Storm Prediction Center and the NARR, were used to determine if the low-level jet was present or not [33]. For Tulsa, OK, soundings from Norman, OK, and Springfield, $\mathrm{MO}$, were both used due to the fact that the sounding locations are equidistant from the Tulsa site and because Tulsa lies along the gradient of the PWater climatology map for a portion of the year. The range and average of each variable were then determined for the $1 \%$ rainfall cases at each location. These values were analyzed at each location and compared to the other study locations within the basin to determine any trends or patterns within the $1 \%$ rainfall events.

To better understand the in-depth methodology used in this research, an ideal case was chosen and analyzed using the methodology described in this section: September 12, 2008, at Wichita, KS. This event yielded the greatest 24-hour rainfall value for the study period in the basin (261.9 $\mathrm{mm}$ of rainfall) and exceeded the next highest rainfall event by nearly $100 \mathrm{~mm}$. Beginning with the synoptic-scale classification, the NARR data was used to analyze the 5day window leading up to the event. From the reanalysis, it was determined that the $500 \mathrm{mb}$ pattern for this event was a positively tilted trough (Figure 4(a)). The NARR also identified the location and influence of the southern Great Plains low-level jet (LLJ) at $850 \mathrm{mb}$ due to its prevalence and ability to transport moisture from April to September (Figure 4(b)) [34, 35]. Archived radar data was then used to classify the event type on the mesoscale. The positively tilted trough and moisture advection from the south resulted in a large area of stratiform rain training over Wichita for much of the day (Figure 4(c)). Finally, the near-event sounding data was gathered and analyzed in order to understand 


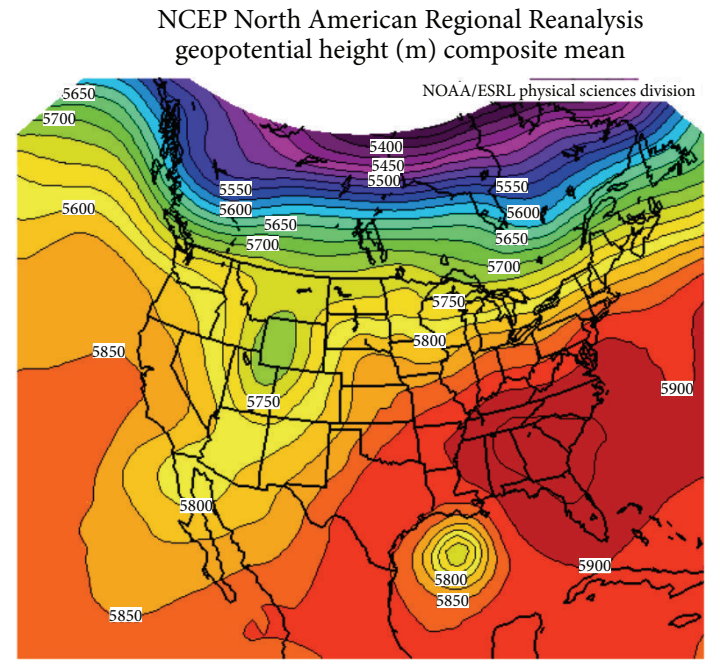

September 12, $200812 Z$

(a)

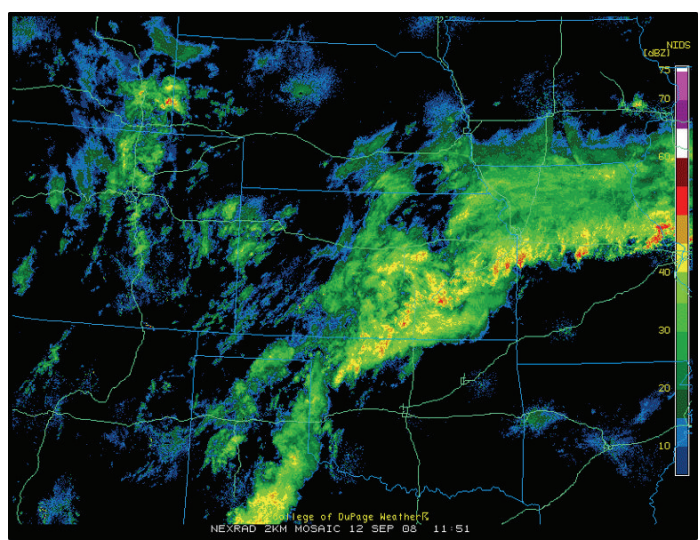

(c)
NCEP North American Regional Reanalysis vector wind $(\mathrm{m} / \mathrm{s})$ composite mean

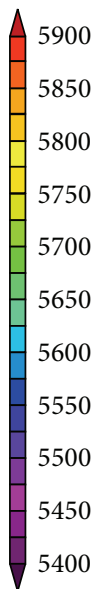

5400

\author{
,
}

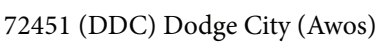

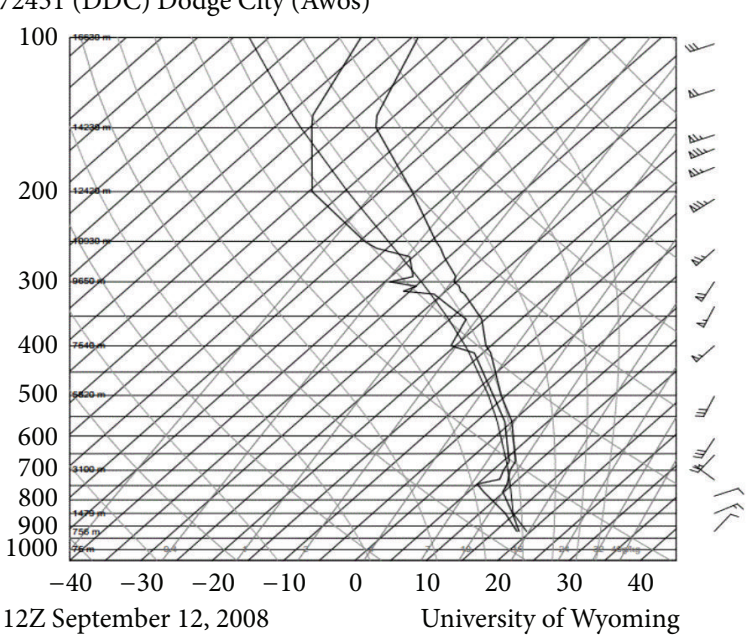

(d)

FIGURE 4: The ideal case for Wichita, KS. (a) $500 \mathrm{mb}$, (b) $850 \mathrm{mb}$, (c) radar still, and (d) sounding for Dodge City.

the atmosphere's thermodynamic profile during each $1 \%$ rainfall event (Figure 4(d) and Table 2). The sounding measured a PWater value of $43.18 \mathrm{~mm}$, which statistically lies between the 99th percentile and maximum value for climatology during this time of year. The WCD of $438.2 \mathrm{mb}$ was the deepest of any case at this location, which consequently resulted in the lowest LCL, highest freezing level, and highest $-10^{\circ} \mathrm{C}$ level at $888.2 \mathrm{mb}, 570 \mathrm{mb}$, and $450 \mathrm{mb}$, respectively.

\section{Results}

Due to the significant precipitation gradient across the Arkansas-Red River Basin, the variability of precipitation processes within this region is high. The synoptic conditions at $500 \mathrm{mb}$ were analyzed leading up to the date of the rainfall events identified in this study (Table 3). The most prominent pattern at $500 \mathrm{mb}$ was the positively tilted trough which
TABLE 2: Sounding parameter values collected from the Dodge City sounding for the ideal Wichita case.

\begin{tabular}{lc}
\hline \multicolumn{2}{c}{ Ideal case sounding information } \\
\hline Sounding Date & September $12,2008,12 \mathrm{Z}$ \\
Rainfall $(\mathrm{mm})$ & 261.9 \\
PWater $(\mathrm{mm})$ & 43.18 \\
CAPE $(\mathrm{J} / \mathrm{kg})$ & 27.72 \\
LCL height $(\mathrm{mb})$ & 888.2 \\
Freezing level $(\mathrm{mb})$ & 570 \\
Negative $10^{\circ} \mathrm{C}$ level $(\mathrm{mb})$ & 450 \\
MLMR $(\mathrm{g} / \mathrm{kg})$ & 13.36 \\
K-Index & 33 \\
WCD $(\mathrm{mb})$ & 438.2 \\
\hline
\end{tabular}

was consistent with the findings of Smith and Younkin [36]. However, the number of cases with this pattern was not 
TABLE 3: The synoptic pattern at $500 \mathrm{mb}$ leading up to the rainfall event at each location.

\begin{tabular}{|c|c|c|c|c|c|c|c|c|}
\hline & \multicolumn{8}{|c|}{ Synoptic pattern at $500 \mathrm{mb}$} \\
\hline & Ft. Smith & Tulsa & Wichita & OKC & Wichita Falls & Dodge City & Amarillo & Colorado Springs \\
\hline Positively tilted trough & 9 & 5 & 8 & 7 & 3 & 7 & 6 & 5 \\
\hline Neutrally tilted trough & 1 & 1 & 2 & 0 & 1 & 0 & 0 & 0 \\
\hline Negatively tilted trough & 0 & 2 & 0 & 3 & 0 & 3 & 2 & 3 \\
\hline Short wave & 5 & 6 & 5 & 4 & 7 & 4 & 2 & 2 \\
\hline Ridge & 4 & 3 & 2 & 1 & 2 & 1 & 4 & 7 \\
\hline Tropical & 1 & 1 & 0 & 1 & 1 & 0 & 0 & 0 \\
\hline
\end{tabular}

TABLE 4: Percentage of cases per synoptic pattern at $500 \mathrm{mb}$ by location.

\begin{tabular}{|c|c|c|c|c|c|c|c|c|c|}
\hline & \multicolumn{9}{|c|}{ Synoptic pattern at $500 \mathrm{mb}$} \\
\hline & Ft. Smith & Tulsa & Wichita & $\mathrm{OKC}$ & Wichita Falls & Dodge City & Amarillo & Colorado Springs & Basin Total \\
\hline Positively tilted trough & $45.00 \%$ & $27.78 \%$ & $47.06 \%$ & $43.75 \%$ & $21.43 \%$ & $46.67 \%$ & $42.86 \%$ & $29.41 \%$ & $38.17 \%$ \\
\hline Neutrally tilted trough & $5.00 \%$ & $5.56 \%$ & $11.76 \%$ & $0.00 \%$ & $7.14 \%$ & $0.00 \%$ & $0.00 \%$ & $0.00 \%$ & $3.82 \%$ \\
\hline Negatively tilted trough & $0.00 \%$ & $11.11 \%$ & $0.00 \%$ & $18.75 \%$ & $0.00 \%$ & $20.00 \%$ & $14.29 \%$ & $17.65 \%$ & $9.92 \%$ \\
\hline Short wave & $25.00 \%$ & $33.33 \%$ & $29.41 \%$ & $25.00 \%$ & $50.00 \%$ & $26.67 \%$ & $14.29 \%$ & $11.76 \%$ & $26.72 \%$ \\
\hline Ridge & $20.00 \%$ & $16.67 \%$ & $11.76 \%$ & $6.25 \%$ & $14.29 \%$ & $6.67 \%$ & $28.57 \%$ & $41.18 \%$ & $18.32 \%$ \\
\hline Tropical & $5.00 \%$ & $5.56 \%$ & $0.00 \%$ & $6.25 \%$ & $7.14 \%$ & $0.00 \%$ & $0.00 \%$ & $0.00 \%$ & $3.05 \%$ \\
\hline
\end{tabular}

TABLE 5: Mesoscale classifications of the cases by location.

\begin{tabular}{|c|c|c|c|c|c|c|c|c|}
\hline & \multicolumn{8}{|c|}{ Mesoscale classifications } \\
\hline & Ft. Smith & Tulsa & Wichita & $\mathrm{OKC}$ & Wichita Falls & Dodge City & Amarillo & Colorado Springs \\
\hline MCS & 5 & 12 & 12 & 9 & 8 & 7 & 2 & 8 \\
\hline Stratiform rain & 10 & 4 & 4 & 3 & 6 & 6 & 2 & 6 \\
\hline Boundary & 1 & 0 & 1 & 0 & 0 & 1 & 2 & 0 \\
\hline Disorganized & 4 & 2 & 0 & 3 & 0 & 1 & 8 & 3 \\
\hline Other & & & & 1 (Erin) & & & & \\
\hline
\end{tabular}

expected. For Ft. Smith, Wichita, Oklahoma City, Dodge City, and Amarillo, the positively tilted trough was the dominant synoptic pattern. Statistically, $40 \%$ of all events within the entire basin exhibited this $500 \mathrm{mb}$ pattern. For the Tulsa and Wichita Falls sites, the short wave classification was the main synoptic pattern while the most prominent pattern at Colorado Springs was a ridging pattern. The latter result is consistent with the findings of Maddox et al. [15] but could also be due to its western location in the basin and higher elevation. Overall, the ridge pattern discussed in Maddox et al. [15] yielded $18 \%$ of the rainfall events within the basin (Table 4). Finally, the southernmost and eastern sites included only limited $1 \%$ events associated with tropical cyclone impacts, contributing to $3 \%$ of all cases in the basin.

The mesoscale classifications determined for each site are displayed in Table 5. Throughout the basin, nearly $50 \%$ of the rainfall events were classified as MCS. As such, the MCS classification was the most prominent mesoscale feature in the basin. Additionally, approximately $30 \%$ of the events were classified as stratiform rain events (Table 6). Further, nearly all the cold season (November-February) events at Ft. Smith, Tulsa, and Wichita were stratiform events. All locations that yielded MCS as the primary mesoscale classification exhibited stratiform rain as the second most prominent radar-indicated feature, which typically trailed the leading convective line or MCS. The only locations that did not have MCS as the most prominent mesoscale feature were Ft. Smith (stratiform) and Amarillo (disorganized).

Data collected from the proximity soundings for each location were also analyzed. Figure 5 displays the results of the eight locations within the basin compared to variables found from soundings. For example, Figure 5(a) plots the magnitude of the rainfall compared with the time of year the rainfall event occurred. The largest number of $1 \%$ rainfall events occurred from April to October. The events that occurred from November to March were mainly stratiform events located in the easternmost part of the basin (Table 7).

Figure 5(b) displays the magnitude of the rainfall compared with the PWater values collected from the sounding data. Overall, the locations to the west, as well as locations with higher station elevation, had reduced PWater values while locations in the eastern part of the basin with lower elevations had greater PWater values. Further, while most of the rainfall events had a magnitude between 50 and $100 \mathrm{~mm}$ despite an increase in PWater values, the overall relationship between the magnitude of the PWater and event magnitude 
TABle 6: Percentage of event per mesoscale classification by location.

\begin{tabular}{lccccccccc}
\hline & & & \multicolumn{5}{c}{ Mesoscale classifications } \\
& Ft. Smith & Tulsa & Wichita & OKC & Wichita & Dodge City & Amarillo & Colorado Springs & Basin Total \\
\hline MCS & $25.00 \%$ & $66.67 \%$ & $70.59 \%$ & $56.25 \%$ & $57.14 \%$ & $46.67 \%$ & $14.29 \%$ & $47.06 \%$ & $48.09 \%$ \\
Stratiform Rain & $50.00 \%$ & $22.22 \%$ & $23.53 \%$ & $18.75 \%$ & $42.86 \%$ & $40.00 \%$ & $14.29 \%$ & $35.29 \%$ & $31.30 \%$ \\
Boundary & $5.00 \%$ & $0.00 \%$ & $5.88 \%$ & $0.00 \%$ & $0.00 \%$ & $6.67 \%$ & $14.29 \%$ & $0.00 \%$ & $3.82 \%$ \\
Disorganized & $20.00 \%$ & $11.11 \%$ & $0.00 \%$ & $18.75 \%$ & $0.00 \%$ & $6.67 \%$ & $57.14 \%$ & $17.65 \%$ & $16.03 \%$ \\
Other & $0.00 \%$ & $0.00 \%$ & $0.00 \%$ & $6.25 \%$ & $0.00 \%$ & $0.00 \%$ & $0.00 \%$ & $0.00 \%$ & $0.76 \%$ \\
\hline
\end{tabular}

TABLE 7: Number of events occurring during the warm season (March-October) and cold season (November to February).

\begin{tabular}{lccccccccc}
\hline & & & \multicolumn{3}{c}{ Season } \\
& Ft. Smith & Tulsa & Wichita & OKC & Wichita Falls & Dodge City & Amarillo & Colorado Springs \\
\hline March-October & 14 & 17 & 16 & 16 & 14 & 15 & 14 & 17 \\
November-February & 6 & 1 & 1 & 0 & 0 & 0 & 0 & 0 \\
\hline
\end{tabular}

was only weakly positive. Additionally, the sites located in the eastern portion of the basin had a larger range of PWater values while the cities to the west had a much smaller range.

When the magnitude of the rainfall events was compared to the CAPE (Figure 5(c)), the results yielded that most events had CAPE values less than $1000 \mathrm{~J} / \mathrm{kg}$. The magnitude of the rainfall compared to the MLMR (Figure 5(d)) behaved similarly to PWater in that the sites to the west yielded lower values per event while sites to the east had higher values with more variability. However, all values within the basin ranged between 5 and $20 \mathrm{~g} / \mathrm{kg}$. Figure 5(e) displays the magnitude of the rainfall compared to the WCD, and again, in general, the locations to the west and with higher elevations had the lowest cloud depths while the locations to the east and with lower elevations had larger depths. In the central part of the basin, the range of cloud depths was small, similar to locations to the west, but the magnitudes were higher similar to the locations in the east (Table 8). When the magnitude of rainfall was compared to the freezing level (Figure 5(f)), the majority of the rainfall events had a freezing level between $575 \mathrm{mb}$ and $650 \mathrm{mb}$. Further, the average freezing level for the entire basin was at $614.7 \mathrm{mb}$ with limited variance in the average between the eastern and western portions of the basin. The range of values for the freezing level was also consistent throughout the basin (Table 8).

\section{Discussion}

Comparing the PWater values to the PWater climatology [37], approximately $86 \%$ of the events were above the 75th percentile on the PWater climatology with less than 3\% being under the 50th percentile (Table 9). These events under the 50 th percentile demonstrate that the magnitude of the rainfall event is not a function of the magnitude of PWater as was expected but a range of complex precipitation processes. Even so, extreme anomalies of PWater (greater than the 99th percentile) were associated with over $25 \%$ of the event cases.

The Arkansas-Red River Basin proved to be a unique area in its variation of precipitation. The important zonal differences between the boundaries of this relatively small basin warranted further examination of how typical 1\% rainfall events' characteristics vary from west to east. Representative cases from Colorado Springs (located at the westernmost point of the basin, on the lee-side foothills of the Rocky Mountains, at an elevation of 1839 meters) and Fort Smith (located on the eastern border of the basin at just 141.1 meters above sea level) were chosen by determining the $1 \%$ rainfall event for each location that exhibited characteristics most similar to the location's average event magnitude and sounding parameters in Table 8.

4.1. Colorado Springs Ideal Case. The representative $1 \%$ case chosen for Colorado Springs yielded $63.2 \mathrm{~mm}$ of rainfall on June 27, 2004, which is only slightly less than the average event magnitude of $68.93 \mathrm{~mm}$. Colorado Springs experienced all of its $1 \%$ rainfall events between the months of April and September. Therefore, late June is the true median of the heavy rainfall season at this location (Figure 6(a)). This event was classified on the synoptic-scale as a $500 \mathrm{mb}$ ridge axis event and on the mesoscale as an MCS, which are the most common patterns found at this location (Tables 3 and 5). The PWater for this event was measured at $23.88 \mathrm{~mm}$, which is nearly consistent with the average location value of $24.6 \mathrm{~mm}$. Statistically, this value is between the 75th and 99th percentile of PWater values from soundings at this time of year. This makes it an exceptionally high value but not necessarily considered as extreme as the 24-hour rainfall. The LCL, MLMR, WCD, and the freezing level observations were also very close to the calculated average values (Figures 6(b)6(f)).

Colorado Springs is a unique location in the basin because it is the only chosen site where precipitation-generating events (convective, frontal, tropical, etc.) are altered by orography [38]. Numerous studies and reviews on orographic precipitation agree that heavy rainfall in mountainous areas is commonly observed with a $500 \mathrm{mb}$ ridge just to the east of the incident area [3, 39-41]. The synoptic setup allows for slow-moving storms due to the weak upper level flow associated with ridging patterns. In addition to the synoptic 


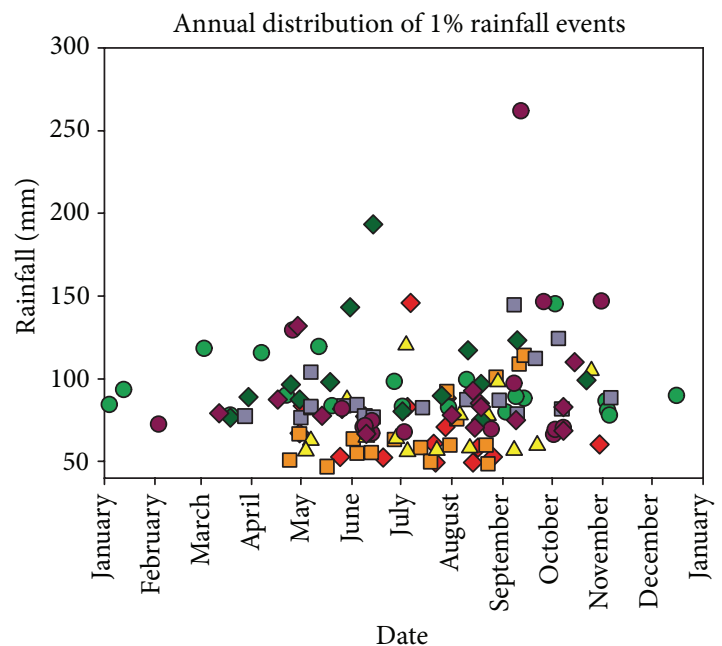

(a)

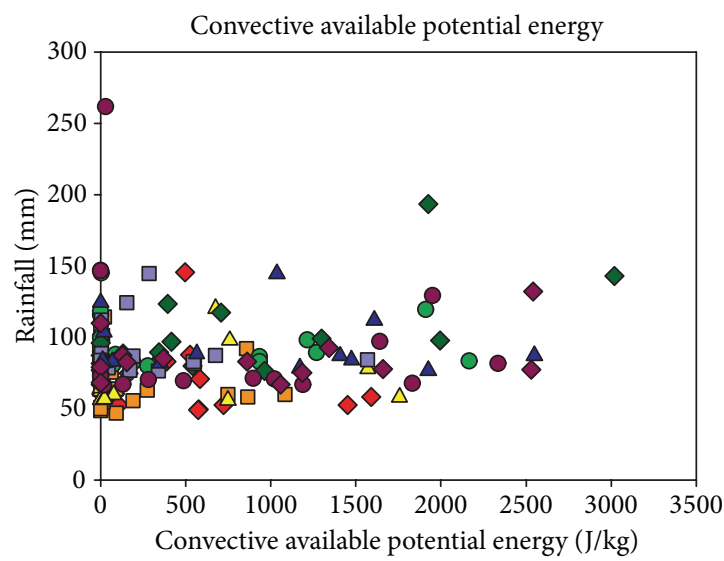

(c)

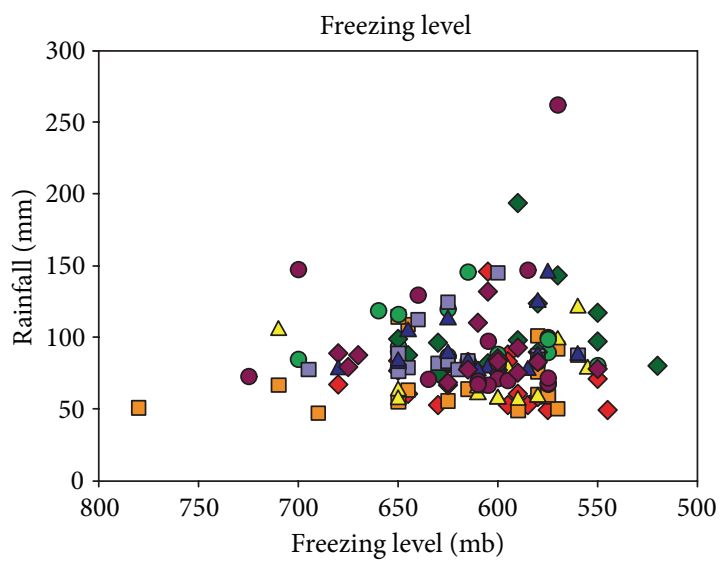

$\diamond$ Amarillo

$\square$ Colorado Springs

$\triangle$ Dodge City

- Ft. Smith

$\diamond$ Oklahoma City

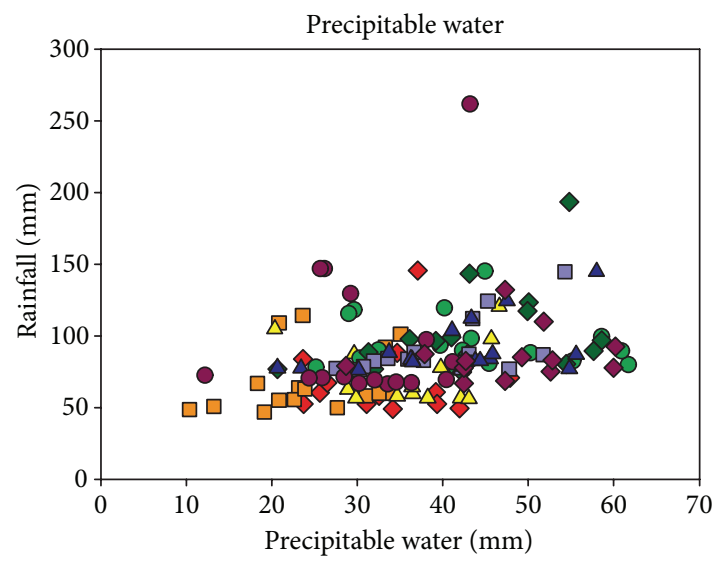

(b)

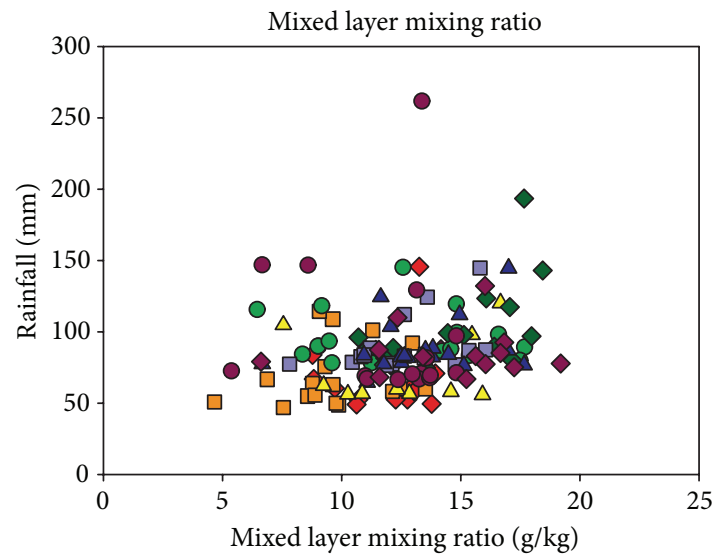

(d)

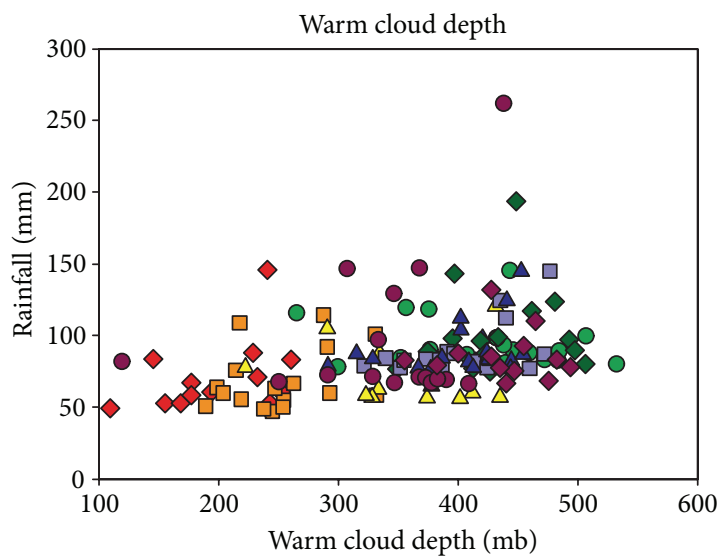

$\checkmark$ Amarillo

ㄷ Colorado Springs

$\triangle$ Dodge City

o Ft. Smith

$\diamond$ Oklahoma City
․ Tulsa (SGF)/Tulsa Airport

- Tulsa (OUN)

- Wichita

$\downarrow$ Wichita Falls

(e)

Figure 5: Basin composite graphs. (a) Annual distribution of $1 \%$ cases. (b) Magnitude of rainfall versus precipitable water. (c) Magnitude of rainfall versus CAPE. (d) Magnitude of rainfall versus MLMR. (e) Magnitude of rainfall versus warm cloud depth. (f) Magnitude of rainfall versus freezing level. 


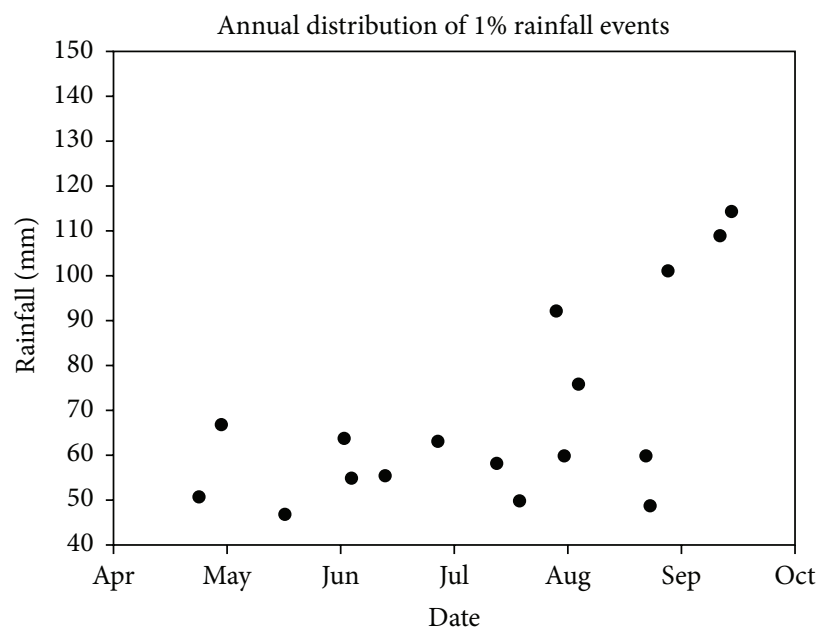

(a)

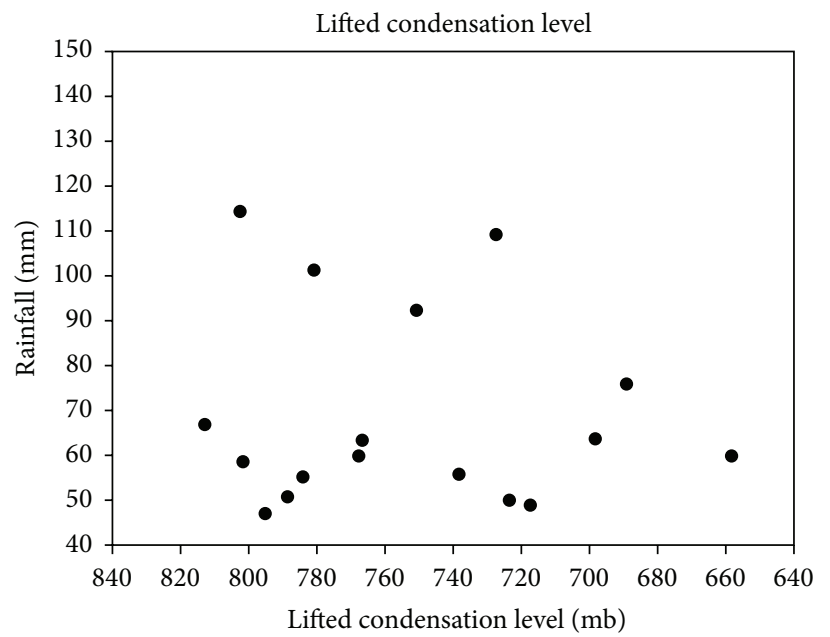

(c)

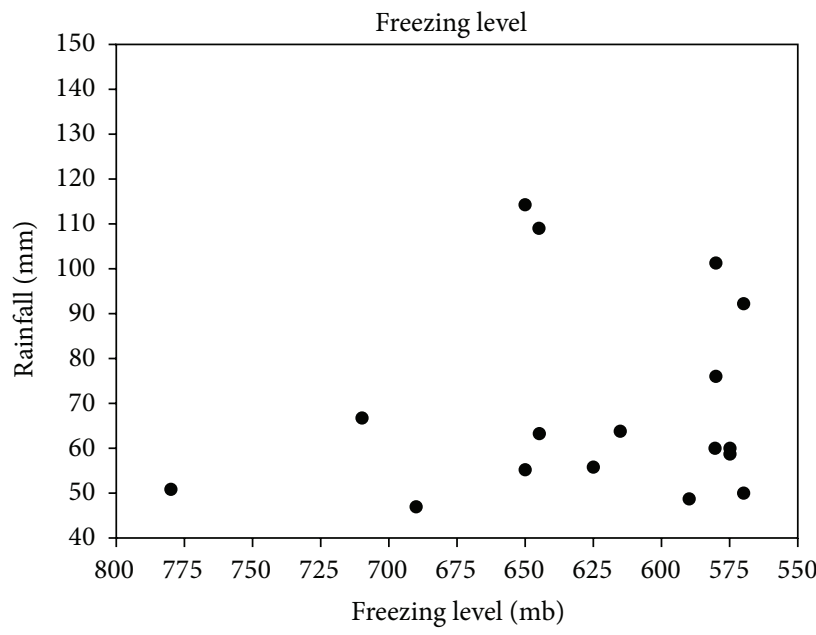

(e)

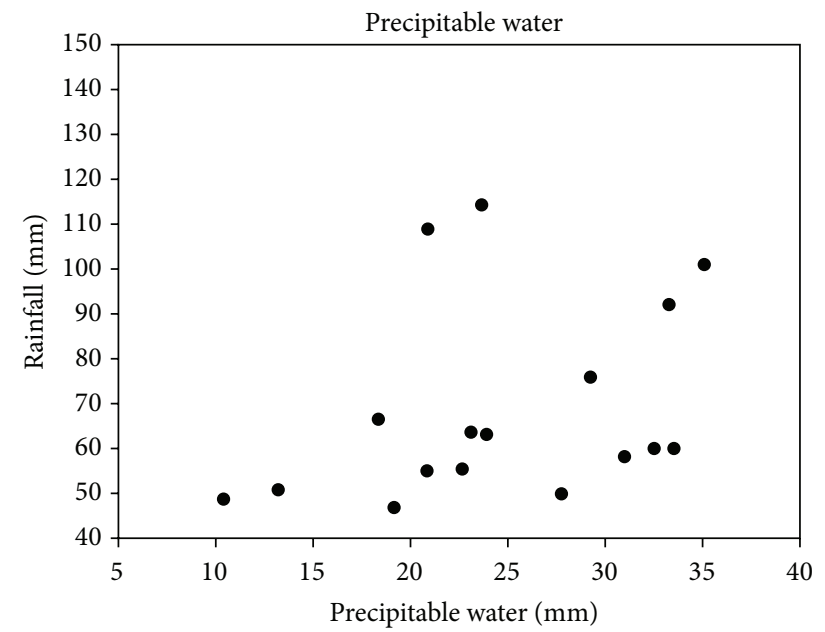

(b)

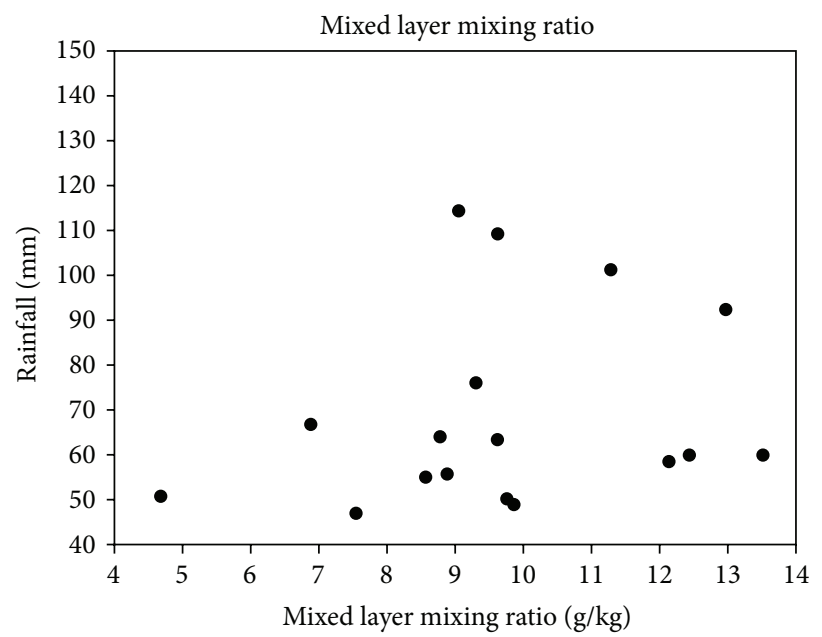

(d)

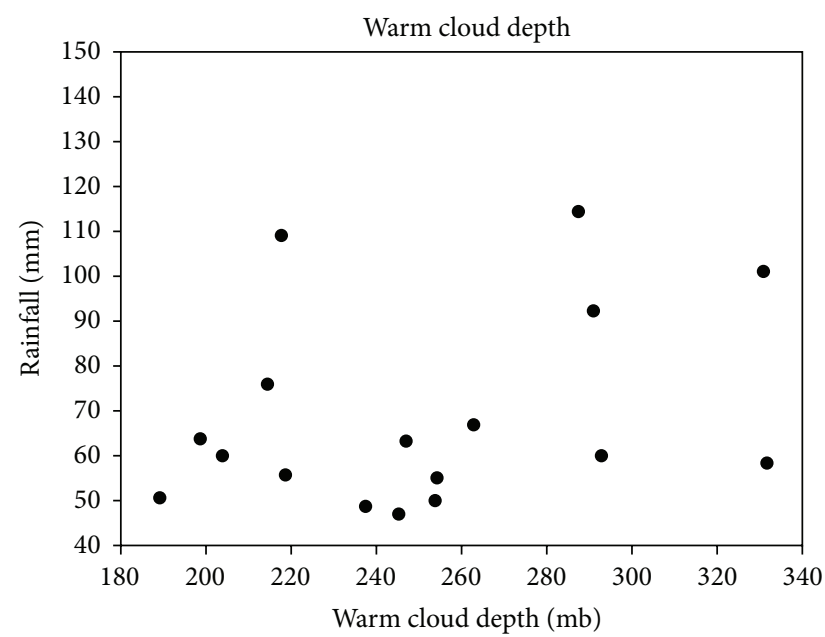

(f)

Figure 6: Colorado Springs graphs. (a) Annual distribution of $1 \%$ cases. (b) Magnitude of rainfall versus PWater. (c) Magnitude of rainfall versus LCL height. (d) Magnitude of rainfall versus MLMR. (e) Magnitude of rainfall versus freezing level. (f) Magnitude of rainfall versus WCD. 
TABLE 8: Minimum, maximum, and average values of sounding parameters for each location as well as the basin average.

\begin{tabular}{|c|c|c|c|c|c|c|c|c|c|c|c|}
\hline & & Ft. Smith & $\begin{array}{l}\text { Tulsa } \\
(\mathrm{SGF}) \\
\end{array}$ & $\begin{array}{c}\text { Tulsa } \\
\text { (OUN) }\end{array}$ & Wichita & OKC & Wichita Falls & Dodge City & Amarillo & $\begin{array}{c}\text { Colorado } \\
\text { Springs } \\
\end{array}$ & Basin average \\
\hline \multirow{3}{*}{ Magnitude } & Min & 78.20 & 76.50 & 76.50 & 66.50 & 74.90 & 66.80 & 56.10 & 49.30 & 47.00 & 65.76 \\
\hline & Avg & 94.32 & 90.80 & 90.80 & 96.04 & 101.56 & 84.99 & 74.23 & 69.69 & 68.93 & 85.55 \\
\hline & Max & 145.30 & 144.80 & 144.80 & 261.90 & 193.50 & 132.10 & 120.40 & 145.80 & 114.3 & 155.88 \\
\hline \multirow{3}{*}{ PWater (mm) } & Min & 25.17 & 27.51 & 20.65 & 12.19 & 20.65 & 28.70 & 20.33 & 23.65 & 10.41 & 20.96 \\
\hline & Avg & 42.68 & 39.66 & 41.05 & 31.34 & 43.53 & 47.32 & 36.68 & 34.24 & 24.60 & 37.77 \\
\hline & Max & 61.67 & 54.29 & 57.96 & 43.18 & 58.58 & 60.20 & 46.58 & 47.84 & 35.05 & 51.71 \\
\hline \multirow{3}{*}{ CAPE } & Min & 0.00 & 0.00 & 0.00 & 0.00 & 0.00 & 0.00 & 0.00 & 0.00 & 0.00 & 0.00 \\
\hline & Avg & 452.60 & 283.01 & 678.49 & 737.99 & 743.40 & 909.87 & 426.72 & 509.37 & 253.73 & 551.86 \\
\hline & Max & 2166.00 & 1569.00 & 2549.00 & 2335.00 & 3018.00 & 2531.00 & 1756.00 & 1590.00 & 1084.00 & 2066.44 \\
\hline \multirow{3}{*}{$\mathrm{LCL}(\mathrm{mb})$} & Min & 805.30 & 814.60 & 755.30 & 787.60 & 876.90 & 890.70 & 692.40 & 684.70 & 658.80 & 774.03 \\
\hline & Avg & 920.78 & 898.71 & 893.68 & 848.18 & 921.69 & 922.95 & 854.39 & 803.34 & 753.41 & 868.81 \\
\hline & Max & 967.20 & 940.00 & 934.00 & 893.10 & 947.90 & 965.80 & 895.30 & 857.60 & 812.90 & 912.64 \\
\hline \multirow{3}{*}{$\mathrm{LCL}(\mathrm{m})$} & Min & 322.00 & 113.00 & 305.00 & 281.00 & 255.00 & 250.00 & 260.00 & 301.00 & 210.00 & 255.22 \\
\hline & Avg & 767.20 & 644.25 & 784.44 & 706.88 & 450.50 & 646.46 & 645.71 & 830.57 & 944.41 & 711.04 \\
\hline & Max & 1822.00 & 1463.00 & 2205.00 & 1953.00 & 805.00 & 1892.00 & 2410.00 & 1901.00 & 2136.00 & 1843.00 \\
\hline \multirow{3}{*}{ MLMR } & Min & 6.46 & 7.80 & 6.66 & 5.37 & 10.71 & 6.62 & 7.55 & 8.76 & 4.67 & 6.82 \\
\hline & Avg & 12.77 & 12.68 & 13.38 & 11.98 & 14.59 & 14.49 & 12.27 & 12.03 & 9.70 & 12.59 \\
\hline & Max & 17.67 & 16.04 & 17.65 & 14.82 & 18.44 & 19.18 & 16.66 & 14.17 & 13.51 & 16.46 \\
\hline \multirow{3}{*}{$K$-Index } & Min & 24.80 & 24.30 & 13.50 & 15.90 & 13.50 & 35.80 & 28.30 & 28.90 & $\mathrm{~N} / \mathrm{A}$ & 20.99 \\
\hline & Avg & 33.47 & 33.71 & 33.92 & 32.62 & 34.64 & 38.08 & 33.68 & 36.33 & $\mathrm{~N} / \mathrm{A}$ & 33.98 \\
\hline & Max & 40.80 & 42.20 & 43.20 & 47.20 & 43.20 & 43.30 & 46.40 & 42.50 & N/A & 43.64 \\
\hline \multirow{3}{*}{ Freezing level } & Min & 550.00 & 560.00 & 560.00 & 570.00 & 520.00 & 550.00 & 555.00 & 545.00 & 570.00 & 553.33 \\
\hline & Avg & 622.25 & 621.25 & 610.28 & 612.81 & 601.25 & 610.38 & 609.29 & 601.43 & 625.29 & 614.70 \\
\hline & Max & 700.00 & 695.00 & 680.00 & 725.00 & 680.00 & 675.00 & 710.00 & 680.00 & 780.00 & 721.67 \\
\hline \multirow{3}{*}{ Neg. $10^{\circ} \mathrm{C}$} & Min & 425.00 & 440.00 & 440.00 & 450.00 & 420.00 & 439.00 & 450.00 & 445.00 & 450.00 & 439.89 \\
\hline & Avg & 501.50 & 497.50 & 493.33 & 507.88 & 488.13 & 493.46 & 487.86 & 482.86 & 501.76 & 495.53 \\
\hline & Max & 575.00 & 560.00 & 550.00 & 635.00 & 560.00 & 555.00 & 590.00 & 550.00 & 600.00 & 575.00 \\
\hline \multirow{3}{*}{ WCD } & Min & 265.30 & 321.80 & 291.70 & 119.30 & 349.30 & 355.70 & 222.40 & 109.70 & 189.10 & 247.14 \\
\hline & Avg & 419.28 & 401.20625 & 400.35 & 339.43 & 433.57 & 437.65 & 366.54 & 201.91 & 251.65 & 360.92 \\
\hline & $\operatorname{Max}$ & 532.60 & 476.70 & 454.40 & 438.20 & 506.60 & 494.20 & 445.30 & 260.80 & 331.80 & 437.84 \\
\hline
\end{tabular}

TABLE 9: Cases compared to the PWater climatology distribution by location.

\begin{tabular}{|c|c|c|c|c|c|c|c|c|c|c|c|}
\hline \multirow[b]{2}{*}{ Percentile } & \multicolumn{11}{|c|}{ PWater climatology range } \\
\hline & $\begin{array}{c}\text { Ft. } \\
\text { Smith }\end{array}$ & $\begin{array}{l}\text { Tulsa } \\
\text { (SGF) }\end{array}$ & $\begin{array}{l}\text { Tulsa } \\
\text { (OUN) }\end{array}$ & Wichita & OKC & $\begin{array}{c}\text { Wichita } \\
\text { Falls }\end{array}$ & $\begin{array}{l}\text { Dodge } \\
\text { City }\end{array}$ & Amarillo & $\begin{array}{l}\text { Colorado } \\
\text { Springs }\end{array}$ & $\begin{array}{l}\text { Basin } \\
\text { total }\end{array}$ & Percentage for basin \\
\hline Min to 25 th & 0 & 0 & 1 & 0 & 0 & 0 & 0 & 0 & 1 & 2 & $1.37 \%$ \\
\hline 25 th to 50 th & 0 & 0 & 0 & 0 & 1 & 0 & 0 & 0 & 0 & 1 & $0.68 \%$ \\
\hline 50 th to 75 th & 3 & 2 & 0 & 4 & 2 & 0 & 1 & 1 & 0 & 13 & $8.90 \%$ \\
\hline 75th to 99 th & 10 & 13 & 11 & 8 & 5 & 4 & 11 & 11 & 14 & 87 & $59.59 \%$ \\
\hline 99th to max & 7 & 1 & 6 & 4 & 7 & 9 & 2 & 2 & 2 & 40 & $27.40 \%$ \\
\hline Unknown & 0 & 0 & 0 & 1 & 0 & 1 & 1 & 0 & 0 & 3 & $2.05 \%$ \\
\hline
\end{tabular}

environment, a variety of mesoscale flow patterns and circulations have been identified to generate long-lasting heavy precipitation events along the Front Range. The presence of a moist, easterly low-level jet has been documented by previous studies in Big Thompson, CO [40-42], during the
Mesoscale Alpine Program [43, 44] and in the northwest Mediterranean area [45]. The zonal low-level jet transports moist, unstable air that converges with southerly synoptic flow along the mountain slopes. Another notable orographic mesoscale feature is a cyclonic circulation that can form 
on the south side of the Rockies as a result of these lowlevel flows and convergence zones $[8,45,46]$. Rotunno and Houze [44] emphasized the need for in-depth mesoscale analysis simply because flows modified by orography can alter the precipitation yield and its spatial distribution. Further research could be achieved through reanalyses focused on event features such as advection, upslope, and downslope flows [47] or how rainfall intensity is correlated with humidity anomalies and low-level mesoscale flows [48, 49]. A better understanding of these events, specifically their fundamental mesoscale processes, could improve forecasting and model guidance for orographically enhanced rain events in the populated, mountainous portion of the basin $[38,50]$.

4.2. Fort Smith Ideal Case. To compare the basin's strong spatial variations, the representative $1 \%$ case chosen for Fort Smith produced $93.5 \mathrm{~mm}$ of rainfall on January 13, 2007. It is important to note that even though this event occurred in what is determined to be the cold season, it yielded entirely liquid precipitation. This event total was less than $1 \mathrm{~mm}$ from the average Fort Smith rainfall magnitude of $94.32 \mathrm{~mm}$. For this $1 \%$ rainfall case, a $500 \mathrm{mb}$ positively tilted trough was identified as the synoptic-scale forcing with subconvective (less than $40 \mathrm{dBZ}$ ) radar returns [18]. Thus, this event was classified as stratiform on the mesoscale. Table 3 shows that the positively tilted trough is the most prominent synopticscale forcing mechanism observed at Fort Smith for 1\% rainfall events. The PWater observed in the sounding for this event was $39.7 \mathrm{~mm}$ which was slightly less than the location average of $42.68 \mathrm{~mm}$, but still between the 99th percentile and maximum PWater value in the climatology for the Little Rock, AR, upper-air site for that time of year. Even though this was a cold season event, the low LCL, deep WCD, and high freezing level, combined high PWater values (Figure 7), allowed for a significant rainfall event occurring at the easternmost location in the basin.

The representative cases for the westernmost and easternmost locations in the Arkansas-Red River Basin are inherently different not only quantitatively but in the types of atmospheric forcings driving these $1 \%$ rainfall events. In a study of extreme rain events by Schumacher and Johnson [18], it was found that summer-time events are typically the result of MCS moving over a particular location. The results at Colorado Springs directly support this finding in the sense that all of the $1 \%$ rainfall events occur in the warm season and the prevailing mesoscale feature was in fact the MCS. Schumacher and Johnson [18] further note that cold season rainfall events are typically synoptic systems enhanced by a strong baroclinic zone. This finding was also supported by the results from the representative case study at the Fort Smith location. A strong, low-level baroclinic zone was present over Fort Smith the morning of the event, with the LLJ present at $850 \mathrm{mb}$. The LLJ served as a mechanism to transport moisture from the Gulf of Mexico.

The results of this study yielded that cold season $1 \%$ rainfall events only occurred in the eastern portion of the basin (Table 7) which could be the reason for the larger range of PWater values in the east in comparison to the western portion of the basin. This is due to the available transport mechanisms in place for locations to receive necessary moisture, despite it being the climatologically drier months of the year. The western portion of the basin's $1 \%$ events is confined to the warm season months due to the absence of this strong baroclinic zone and lack of moisture transport from the southern plains LLJ as seen in the east.

4.3. Oklahoma City Ideal Case. While west to east differences are intriguing, it is also important to note the findings in the transition zone between the Rocky Mountains and the lowlying eastern portion of the basin. Oklahoma City was chosen due to its metropolitan location in the heart of the ArkansasRed River Basin. The most prominent synoptic feature at this location was the positively tilted trough, similar to the pattern found in Fort Smith. This upper-atmospheric pattern accounted for 7 of the 16 total $1 \%$ cases and also was the direct forcing in the "ideal" case for Oklahoma City on June 14,2010 , that produced $193.5 \mathrm{~mm}$ of rain and significant local flash flooding. On the mesoscale, seven of the total cases were the result of MCS, similar to the mesoscale patterns found at Colorado Springs. However, some of the greatest rainfall events for Oklahoma City came from the stalling of an outflow boundary, as well as the inland reintensification of Tropical Storm Erin.

The June 14, 2010, event, fueled by a stationary convective outflow boundary, contributed to the rainiest 2-day period in Oklahoma City history [51]. The measured PWater was near the top of all values for the $1 \%$ cases, reaching a maximum value of $54.79 \mathrm{~mm}$. This value statistically lies between the 99th and maximum percentiles for OUN upper air at this time of year. While it was expected that the highest magnitude events would have the highest CAPE, some events had extremely high CAPE while many had $0 \mathrm{~J} / \mathrm{kg}$ of CAPE. This case in particular had unusually high CAPE value of $1924 \mathrm{~J} / \mathrm{kg}$, unlike most other cases at any location in the basin. It is important to note that the $K$-Index was high, as expected, since this was a predominately convective event. The moisture was advected from the Gulf of Mexico by the LLJ which served as a type of atmospheric river from the Caribbean called the "Maya Express" [52]. This resulted in moisture convergence along the outflow boundary, prolonged convection, and approximately $200 \mathrm{~mm}$ of rainfall [51].

On August 19, 2007, Tropical Storm Erin reintensified over the Oklahoma City area producing $97 \mathrm{~mm}$ of rain. Erin reintensified over land due to a large amount of evapotranspiration caused by heavy rainfall followed by a warming trend in the prior weeks. On the day of the event, the LLJ interacted with a strong low-level baroclinic zone, fueling the rapid intensification of the cyclone. Interestingly, Tropical Storm Erin recorded a lower surface pressure over land than what was recorded over water during its life cycle [53]. The observed PWater value was the most extreme of all the $1 \%$ cases, reaching a value of $58.58 \mathrm{~mm}$, which statistically lies between the 99th and maximum percentiles on the PWater climatology. Similar to the June 14, 2010, case, Erin's reintensification had high MLMR and $K$-Index values as well as the influence of the LLJ. 


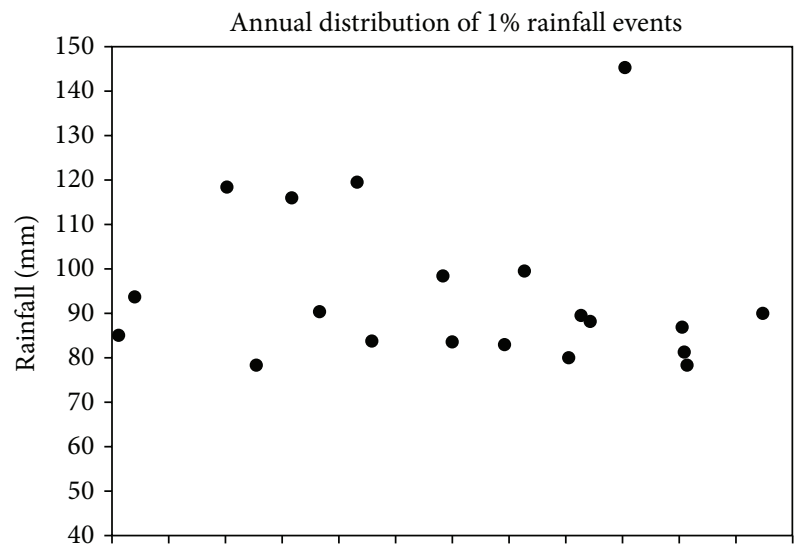

Jan Feb Mar Apr May Jun Jul Aug Sep Oct Nov Dec Jan Date

(a)

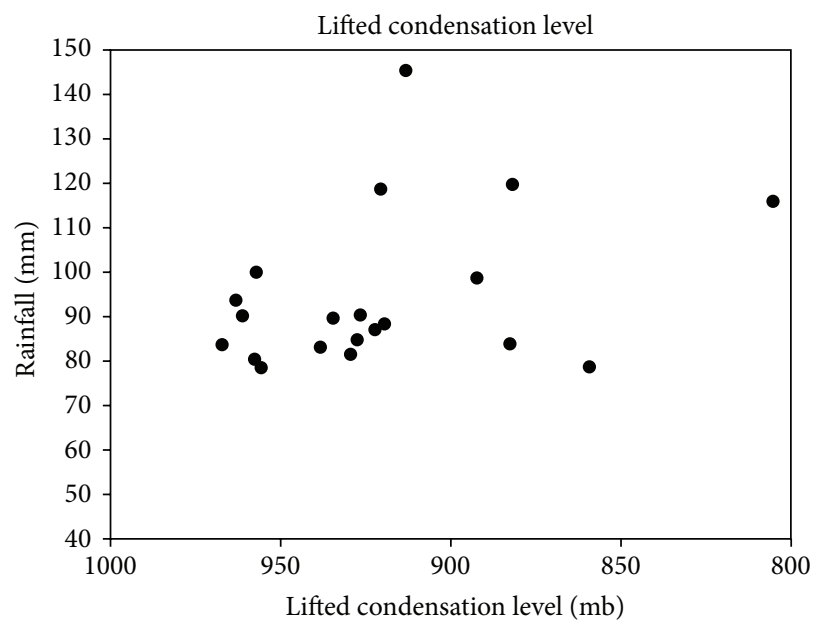

(c)

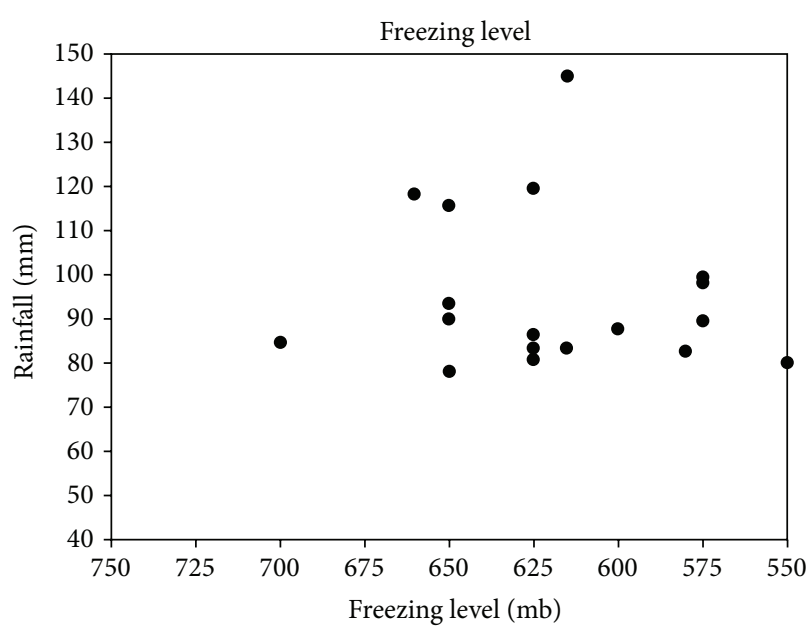

(e)

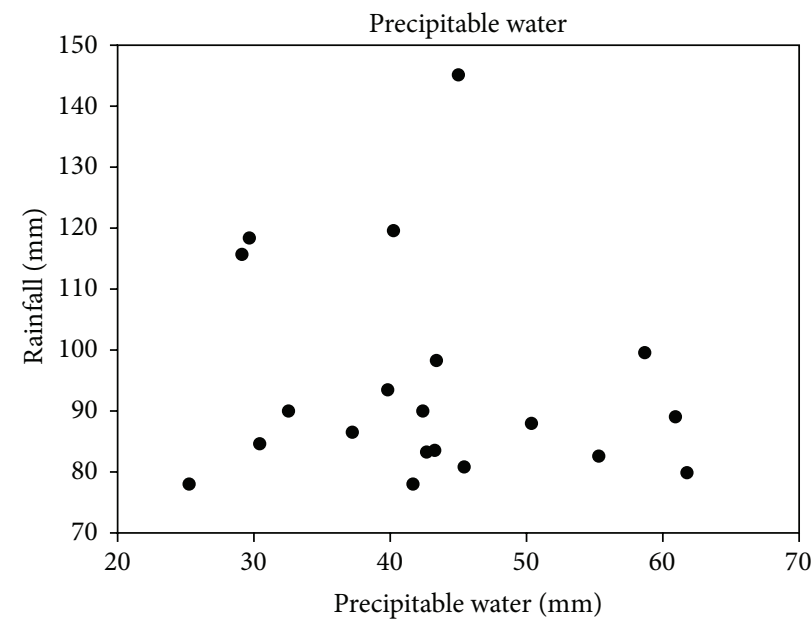

(b)

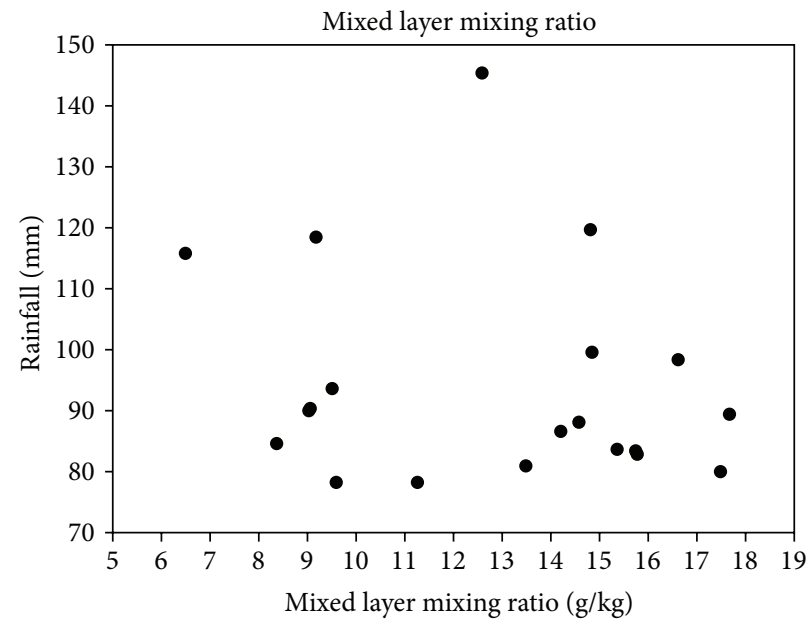

(d)

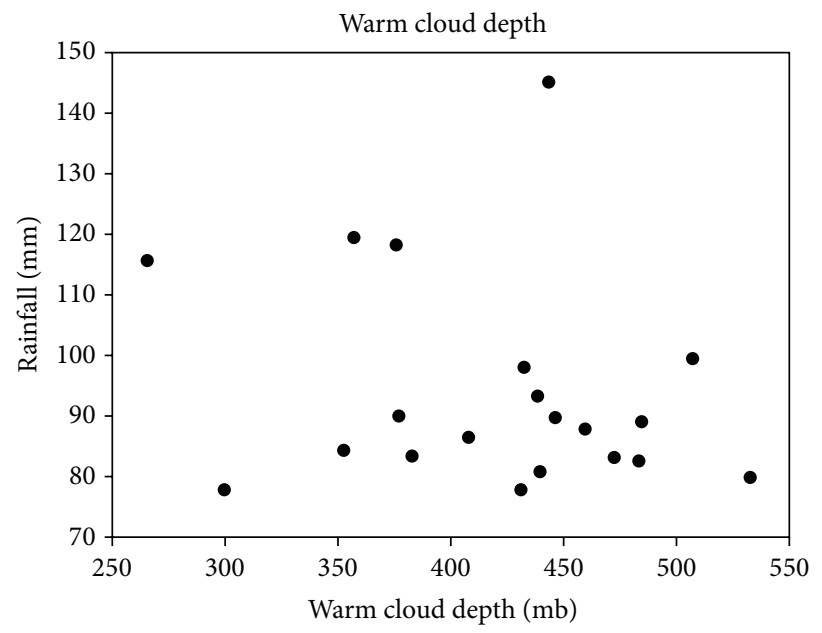

(f)

FIGURE 7: Ft. Smith graphs. (a) Annual distribution of 1\% cases. (b) Magnitude of rainfall versus PWater. (c) Magnitude of rainfall versus LCL height. (d) Magnitude of rainfall versus MLMR. (e) Magnitude of rainfall versus freezing level. (f) Magnitude of rainfall versus WCD. 


\section{Conclusions}

Many conclusions can be drawn from the accumulated datasets and analyses, but a few key findings were proven to be the most profound:

(1) It was expected that the PWater value would increase as a function of event magnitude at all locations. The study found that a range of PWater values exists for $1 \%$ rainfall events of roughly the same magnitude at a given location. Thus, while a weak positive correlation exists between the magnitudes of the two variables, the stronger relationship between the magnitudes of the precipitation event was associated with the departure from climatology at that time of year for each location.

(2) The magnitude of CAPE had little to no correlation with rainfall yield for any given event. At least one $1 \%$ rainfall event at every location experienced an event where $0 \mathrm{~J} / \mathrm{kg}$ was measured, whereas other events measured CAPE upwards of $1000 \mathrm{~J} / \mathrm{kg}$.

(3) The minimum threshold for an event to be considered a $1 \%$ rainfall magnitude increased spatially from the westernmost to the easternmost location. This was expected as the precipitation gradient increases from west to east in the Arkansas-Red River Basin.

(4) Warm season $1 \%$ rainfall events were documented at all eight locations in the basin and were a result of the mesoscale processes that drive convective rainfall. Cold season $1 \%$ rainfall events only occurred at the easternmost locations in the basin and were nearly all classified as synoptically forced stratiform rainfall.

(5) WCD increased zonally from west to east at locations across the basin. The shallowest depths were measured in the west and deepest warm clouds in the east. It appears that this is due to the spatial availability of moisture as well as the difference in elevation between stations in the east and west. Eastern locations are located at a lower elevation and thus have larger WCD.

(6) The average observed freezing level for all 131 cases in the basin was $614.7 \mathrm{mb}$. Unlike the other thermodynamic parameters, there was little east to west variance in the average freezing level observed at each location in the basin.

(7) The LLJ was identified as a low-level forcing at the $850 \mathrm{mb}$ level in one-third of all the cases examined.

(8) MLMR values varied greatly for $1 \%$ rainfall events at each location in the basin. It appears that this variable was strongly dependent on the time of year and available moisture in the atmosphere.

The ultimate goal of this research was to further the endeavors of forecasting heavy precipitation events that could result in flash flooding of areas in the Arkansas-Red River Basin. This climatological analysis of heavy precipitation events will provide forecasters with a readily available compilation of upper-atmospheric patterns and attributes of thermodynamic profiles specific to a location in the basin that are conducive to these extreme events.

\section{Conflict of Interests}

The authors declare that there is no conflict of interests regarding the publication of this paper.

\section{Acknowledgments}

The authors would like to thank Bill Lawrence and his team at the Arkansas-Red River Forecast Center for their helpful suggestions concerning this study. They would also like to thank Brad Illston and Jared Bostic with Oklahoma Climatological Survey for their expertise and guidance during the research period. This work was supported, in part, by the NOAA Climate Program Office's Sectoral Applications Research Program (SARP) Grant NA130AR4310122 and the Agriculture and Food Research Initiative Competitive Grant no. 2012-02355 from the USDA National Institute of Food and Agriculture.

\section{References}

[1] J. J. Gourley, J. M. Erlingis, Y. Hong, and E. B. Wells, "Evaluation of tools used for monitoring and forecasting flash floods in the United States," Weather and Forecasting, vol. 27, no. 1, pp. 158173, 2012.

[2] National Weather Service, "Hydrologic Information CenterFlood Loss Data," 2014, http://www.nws.noaa.gov/hic/.

[3] C. A. Doswell III, H. E. Brooks, and R. A. Maddox, "Flash flood forecasting: an ingredients-based methodology," Weather and Forecasting, vol. 11, no. 4, pp. 560-581, 1996.

[4] E. Gruntfest and C. J. Huber, "Toward a comprehensive national assessment of flash flooding in the United-States," Episodes, vol. 14, no. 1, pp. 26-35, 1991.

[5] L. Marchi, M. Borga, E. Preciso, and E. Gaume, "Characterisation of selected extreme flash floods in Europe and implications for flood risk management," Journal of Hydrology, vol. 394, no. 1-2, pp. 118-133, 2010.

[6] S. Rozalis, E. Morin, Y. Yair, and C. Price, "Flash flood prediction using an uncalibrated hydrological model and radar rainfall data in a Mediterranean watershed under changing hydrological conditions," Journal of Hydrology, vol. 394, no. 1-2, pp. 245255, 2010.

[7] M. Borga, E. N. Anagnostou, G. Blöschl, and J.-D. Creutin, "Flash flood forecasting, warning and risk management: the HYDRATE project," Environmental Science and Policy, vol. 14, no. 7, pp. 834-844, 2011.

[8] D. Gochis, R. Schumacher, K. Friedrich et al., "The great Colorado flood of September 2013," Bulletin of the American Meteorological Society, vol. 96, no. 9, pp. 1461-1487, 2015.

[9] J. A. Moody, R. A. Shakesby, P. R. Robichaud, S. H. Cannon, and D. A. Martin, "Current research issues related to post-wildfire runoff and erosion processes," Earth-Science Reviews, vol. 122, pp. 10-37, 2013.

[10] PRISM Climate Group, 30 Year Normals, 2014, http://www .prism.oregonstate.edu/normals/. 
[11] H. E. Brooks and D. J. Stensrud, "Climatology of heavy rain events in the United States from hourly precipitation observations," Monthly Weather Review, vol. 128, no. 4, pp. 1194-1201, 2000.

[12] T. W. Funk, "Forecasting techniques utilized by the forecast branch of the national meteorological center during a major convective rainfall event," Weather and Forecasting, vol. 6, no. 4, pp. 548-564, 1991.

[13] T. Kleinen and G. Petschel-Held, "Integrated assessment of changes in flooding probabilities due to climate change," Climatic Change, vol. 81, no. 3-4, pp. 283-312, 2007.

[14] M. Beniston, M. Stoffel, and M. Hill, "Impacts of climatic change on water and natural hazards in the Alps: Can current water governance cope with future challenges? Examples from the European 'ACQWA' project," Environmental Science and Policy, vol. 14, no. 7, pp. 734-743, 2011.

[15] R. A. Maddox, C. F. Chappell, and L. R. Hoxit, "Synoptic and meso- $\alpha$ scale aspects of flash flood events," Bulletin of the American Meteorological Society, vol. 60, no. 2, pp. 115-123, 1979.

[16] R. S. Schumacher and R. H. Johnson, "Mesoscale processes contributing to extreme rainfall in a midlatitude warm-season flash flood," Monthly Weather Review, vol. 136, no. 10, pp. 39643986, 2008.

[17] S. T. Ashley and W. S. Ashley, "The storm morphology of deadly flooding events in the United States," International Journal of Climatology, vol. 28, no. 4, pp. 493-503, 2008.

[18] R. S. Schumacher and R. H. Johnson, "Characteristics of U.S. extreme rain events during 1999-2003," Weather and Forecasting, vol. 21, no. 1, pp. 69-85, 2006.

[19] R. S. Schumacher, "Ensemble-based analysis of factors leading to the development of a multiday warm-season heavy rain event," Monthly Weather Review, vol. 139, no. 9, pp. 3016-3035, 2011.

[20] National Weather Service River Forecast Center, "Arkansas-Red Basin," 2015, http://www.srh.noaa.gov/abrfc/.

[21] W. L. Webb, W. K. Lauenroth, S. R. Szarek, and R. S. Kinerson, "Primary production and abiotic controls in forests, grasslands, and desert ecosystems in the United States," Ecology, vol. 64, no. 1, pp. 134-151, 1983.

[22] I. C. Burke, W. K. Lauenroth, and W. J. Parton, "Regional and temporal variation in net primary production and nitrogen mineralization in grasslands," Ecology, vol. 78, no. 5, pp. 13301340, 1997.

[23] P. A. Matson and P. M. Vitousek, "Cross-system comparisons of soil nitrogen transformations and nitrous oxide flux in tropical forest ecosystems," Global Biogeochemical Cycles, vol. 1, no. 2, pp. 163-170, 1987.

[24] V. Meentemeyer, "The geography of organic decomposition rates," Annals of the Association of American Geographers, vol. 74, no. 4, pp. 551-560, 1984.

[25] A. G. Barnston and P. T. Schickedanz, "The effect of irrigation on warm season precipitation in the southern Great Plains," Journal of Applied Meteorology and Climatology, vol. 23, no. 6, pp. 865$888,1984$.

[26] R. Atlas, N. Wolfson, and J. Terry, "The effect of SST and soil moisture anomalies on GLA model simulations of the 1988 US summer drought," Journal of Climate, vol. 6, no. 11, pp. 20342048, 1993.

[27] N. Wolfson, R. Atlas, and Y. C. Sud, "Numerical experiments related to the summer 1980 US heat wave," Monthly Weather Review, vol. 115, no. 7, pp. 1345-1357, 1987.
[28] R. D. Koster, M. J. Suarez, and M. Heiser, "Variance and predictability of precipitation at seasonal-to-interannual timescales," Journal of Hydrometeorology, vol. 1, no. 1, pp. 26-46, 2000.

[29] J. B. Basara, D. S. Arndt, H. L. Johnson, J. G. Brotzge, and K. C. Crawford, "An analysis of the drought of 1998 using the Oklahoma Mesonet," Eos Transactions, vol. 79, p. 258, 1998.

[30] M. J. Menne, I. Durre, R. S. Vose, B. E. Gleason, and T. G. Houston, "An overview of the global historical climatology network-daily database," Journal of Atmospheric and Oceanic Technology, vol. 29, no. 7, pp. 897-910, 2012.

[31] F. Mesinger, G. DiMego, E. Kalnay et al., "North American regional reanalysis," Bulletin of the American Meteorological Society, vol. 87, no. 3, pp. 343-360, 2006.

[32] National Weather Service, Upper-Air Climatology, 2015, http:// www.weather.gov/unr/uac.

[33] R. W. Higgins, Y. Yao, E. S. Yarosh, J. E. Janowiak, and K. C. Mo, "Influence of the great plains low-level jet on summertime precipitation and moisture transport over the central United States," Journal of Climate, vol. 10, no. 3, pp. 481-507, 1997.

[34] W. D. Bonner, "Climatology of the low level jet," Monthly Weather Review, vol. 96, no. 12, pp. 833-850, 1968.

[35] H. M. Helfand and S. D. Schubert, "Climatology of the simulated great plains low-level jet and its contribution to the continental moisture budget of the united states," Journal of Climate, vol. 8, no. 4, pp. 784-806, 1995.

[36] W. Smith and R. J. Younkin, "An operationally useful relationship between the polar jet stream and heavy precipitation," Monthly Weather Review, vol. 100, no. 6, pp. 434-440, 1972.

[37] Storm Prediction Center, "Sounding Climatology Page," 2015, http://www.spc.noaa.gov/exper/soundingclimo/.

[38] R. A. Houze Jr., "Orographic effects on precipitating clouds," Reviews of Geophysics, vol. 50, no. 1, Article ID RG1001, 2012.

[39] Y.-L. Lin, S. Chiao, T.-A. Wang, M. L. Kaplan, and R. P. Weglarz, "Some common ingredients for heavy orographic rainfall," Weather and Forecasting, vol. 16, no. 6, pp. 633-660, 2001.

[40] R. A. Maddox, L. R. Hoxit, C. F. Chappell, and F. Caracena, "Comparison of meteorological aspects of the Big Thompson and Rapid City flash floods," Monthly Weather Review, vol. 106, no. 3, pp. 375-389, 1978.

[41] F. Caracena, R. A. Maddox, L. R. Hoxiy, and C. F. Chappell, "Mesoanalysis of the Big Thompson storm," Monthly Weather Review, vol. 107, no. 1, pp. 1-17, 1979.

[42] D. F. Tucker and N. A. Crook, "The generation of a mesoscale convective system from mountain convection," Monthly Weather Review, vol. 127, no. 6, pp. 1259-1273, 1999.

[43] P. Bougeault, P. Binder, A. Buzzi et al., "The MAP special observing period," Bulletin of the American Meteorological Society, vol. 82, no. 3, pp. 433-462, 2001.

[44] R. Rotunno and R. A. Houze, "Lessons on orographic precipitation from the Mesoscale Alpine Programme," Quarterly Journal of the Royal Meteorological Society, vol.133, no. 625, pp. 811-830, 2007.

[45] D. Ricard, V. Ducrocq, and L. Auger, "A climatology of the mesoscale environment associated with heavily precipitating events over a northwestern Mediterranean area," Journal of Applied Meteorology and Climatology, vol. 51, no. 3, pp. 468-488, 2012.

[46] L. A. Byerle and J. Paegle, "Modulation of the Great Plains lowlevel jet and moisture transports by orography and large-scale circulations," Journal of Geophysical Research D: Atmospheres, vol. 108, no. 16, article 8611, 2003. 
[47] R. B. Smith, "A linear upslope-time-delay model for orographic precipitation," Journal of Hydrology, vol. 282, no. 1-4, pp. 2-9, 2003.

[48] N. Asencio, J. Stein, M. Chong, and F. Gheusi, "Analysis and simulation of local and regional conditions for the rainfall over the Lago Maggiore Target Area during MAP IOP 2b," Quarterly Journal of the Royal Meteorological Society, vol. 129, no. 588, pp. 565-586, 2003.

[49] J.-F. Georgis, F. Roux, M. Chong, and S. Pradier, "TripleDoppler radar analysis of the heavy rain event observed in the Lago Maggiore region during MAP IOP 2b," Quarterly Journal of the Royal Meteorological Society, vol. 129, no. 588, pp. 495-522, 2003.

[50] R. A. Houze Jr., K. L. Rasmussen, S. Medina, S. R. Brodzik, and U. Romatschke, "Anomalous atmospheric events leading to the summer 2010 floods in Pakistan," Bulletin of the American Meteorological Society, vol. 92, no. 3, pp. 291-298, 2011.

[51] R. W. Higgins, V. E. Kousky, and P. Xie, "Extreme precipitation events in the south-central United States during May and June 2010: historical perspective, role of ENSO, and trends," Journal of Hydrometeorology, vol. 12, no. 5, pp. 1056-1070, 2011.

[52] P. A. Dirmeyer and J. L. Kinter III, “The "Maya Express": floods in the U.S. Midwest," Eos, vol. 90, no. 12, pp. 101-102, 2009.

[53] D. S. Arndt, J. B. Basara, R. A. McPherson, B. G. Illston, G. D. McManus And, and D. B. Demko, "Observations of the overland reintensification of tropical storm Erin (2007)," Bulletin of the American Meteorological Society, vol. 90, no. 8, pp. 1079-1093, 2009. 

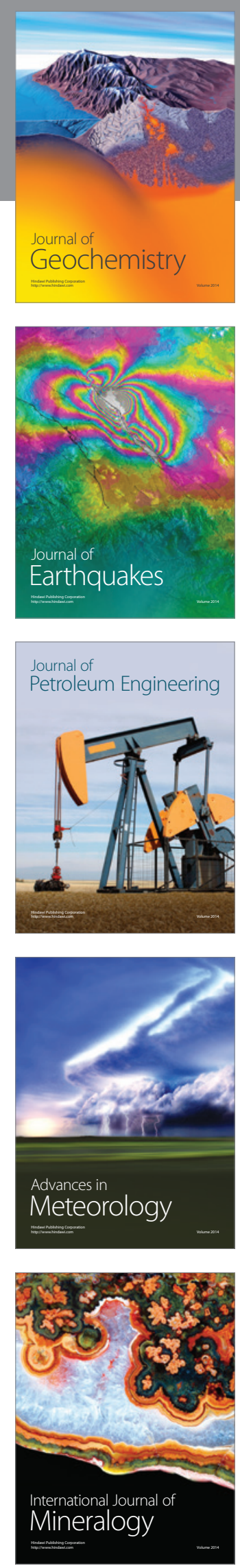
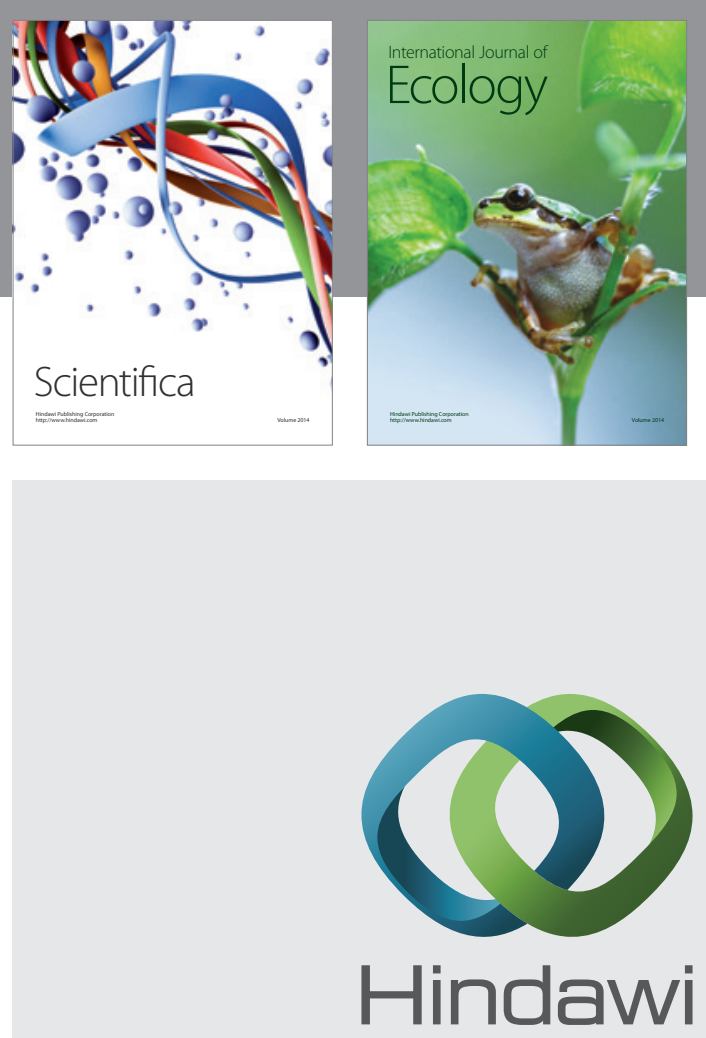

Submit your manuscripts at

http://www.hindawi.com
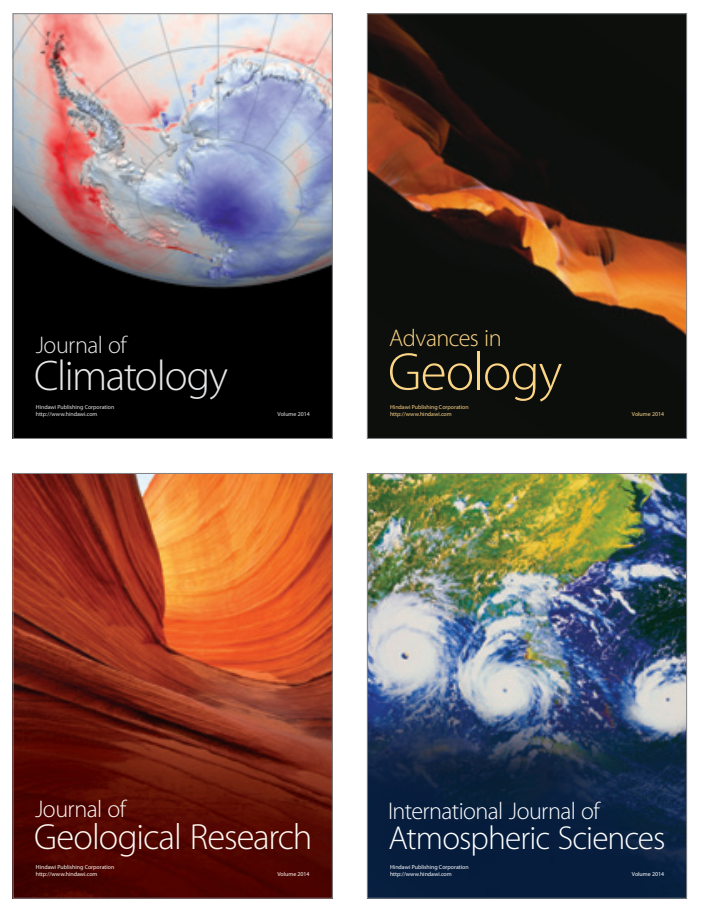

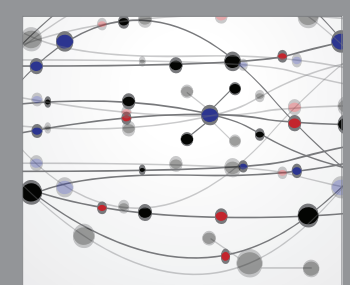

The Scientific

\section{World Journal}
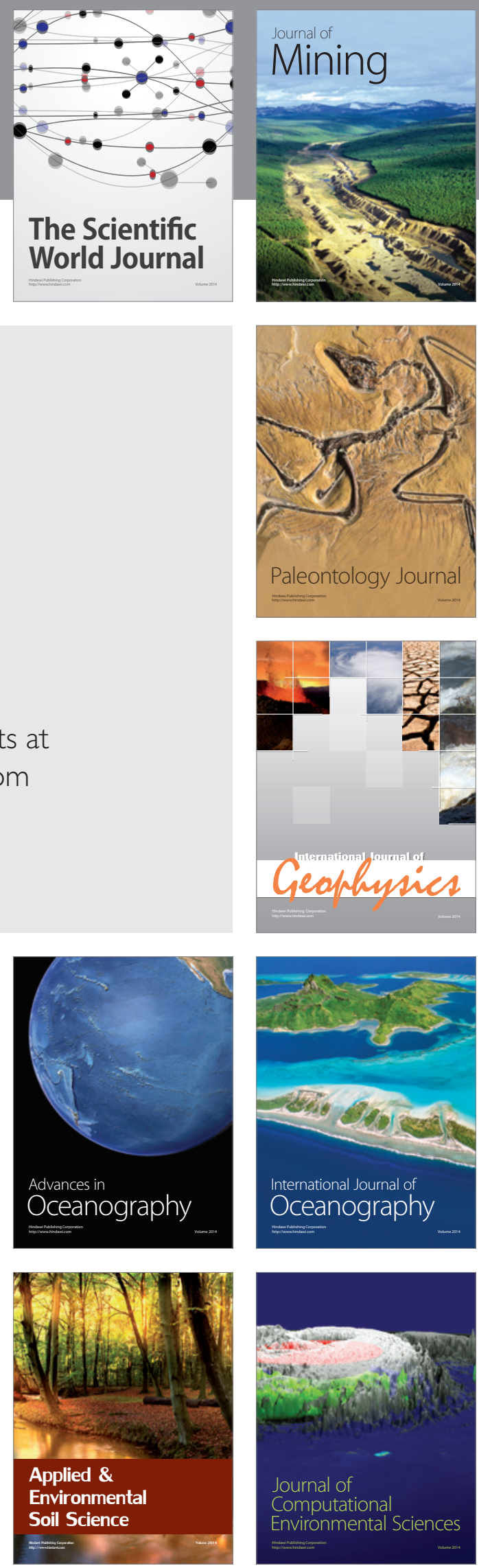